\title{
Numerical simulation of an ice-strengthened bulk carrier in brash ice channel
}

\author{
Wanzhen Luo ${ }^{12}$, Dapeng Jiang ${ }^{12}$, Tiecheng $\mathbf{W u}^{12^{*}}$, Chunyu Guo ${ }^{3}$, Chao Wang ${ }^{3}$, Rui Deng ${ }^{12}$, Saishuai Dai ${ }^{4}$
}

1 School of Marine Engineering and Technology, Sun Yat-sen University, Zhuhai 519000, China;

2 Southern Marine Science and Engineering Guangdong Laboratory (Zhuhai), Zhuhai 519000, China;

3 College of Shipbuilding Engineering, Harbin Engineering University, Harbin 150001, China;

4 Department of Naval Architecture, Ocean and Marine Engineering, University of Strathclyde, Glasgow G4 OLZ, U.K.

*Corresponding author, Tel: +86-18745147797, E-mail address: wutch7@ mail.sysu.edu.cn

\begin{abstract}
In this paper, the CFD-DEM coupling numerical method was applied to study the ship resistance of a certain type of ice-strengthened Panama bulk carrier in the brash ice channel. The ship-water interaction is established under Euler framework, and the ship-ice interaction is realized by means of the DEM method under Lagrange framework. The DEM ice particles modelling and the establishment of numerical brash ice channel were firstly carried out with reference to the HSVA ice tank test image and test parameters. Next, the influence of DEM ice particle shape on contact force and ship-ice interaction was studied. After that, the influence of the one-way coupling and two-way coupling computational scheme between fluid and particles on the calculation accuracy and the interaction phenomenon was studied and analyzed. Finally, the ship- ice interaction process and mechanical behavior of ship and particle interaction in the brash ice channel was simulated, and the numerical results were compared with the experiment of HSVA ice tank. The results show that the CFD-DEM coupling numerical method which takes full account of the effect of ship-water and the interaction between fluid and particles, can well simulate the phenomenon and process of ship-ice interaction, and compared with the experimental results, the average error of the numerical prediction is about 5.03 5.23\% for ICE-1 case with one-way and two-way coupling. The CFD-DEM coupling numerical method includes water resistance, which improves the prediction accuracy of the alone DEM calculation method. The research work in this paper can provide a reference for the numerical prediction of navigation process of ships in the brash ice channel.
\end{abstract}

Keywords: ice-strengthened bulk carrier, brash ice channel, discrete element method, CFD-DEM, resistance

\section{Introduction}

In recent years, with the development of resource and route in Polar Regions, the research on ice-going ships has become increasingly important. Apart from water resistance, ice contributes significantly to the total resistance 
of an ice-going ship when travelling in brash ice channel. A better understanding of ice-ship interaction and accurate prediction of ice induced resistance are critical to ship design and optimization. To date, theoretical analysis, empirical formulas, numerical simulations and model testing are most popular ways of investigating ice-ship interaction. Among the above methods, both empirical and theoretical methods require large amount of experimental data or field measurement in addition to their sensitivity to ship types (hull shapes). Despite of the merit of providing most reliable data, tank testing of ice-ship interaction is, however, not affordable to most researchers due to the high cost associated with the ice tank and ice generation. With the rapid development of computer technologies, numerical simulation methods such as Computational Fluid Dynamics (CFD) are no longer prohibitively demanding regarding computer resources, and have thus received increasing attention over the last decade.

In 1978, Cundall and Strack (1978) developed (Cundall, P. et al, 1978) a Discrete Element Method (DEM) to investigate multi-body interaction. Later on, Hansen et al applied a 2D disc DEM method to study ship-ice interaction (Hansen, E. H. et al, 1999). In their study, a Linear viscoelastic model was employed to simulate the interaction forces between each of the two ice blocks, where those ice blocks were modelled by the aforementioned 2D disc. This laid a foundation for the application of the earliest and recent discrete element method for calculation of ice-ship interactions in brash ice areas. Morgan et al. (Morgan, D., 2015, 2016), and Yulmetov et al (Yulmetov, R. et al, 2017) used LIGGGHTS software based on DEM to simulate the interaction between ice and structures. In 2007, Valanto used finite element method (FEM) to calculate ship sailing process in level ice and effectively predicted ship resistance. Lau et al. used the discrete element method to simulate the damage process and ship resistance of ship-ice interaction (Lau et al, 2011). Zhan et al. simulated the ship maneuverability in crushed ice area and verified the influence of ship resistance on the maneuverability in crushed ice area (Zhan et al, 2010). Kim et al. used finite element software LS-DYNA to simulate the resistance in crushed ice channel (Kim et al, 2013). The simulation results were compared with the experimental results of Korea Research Institute of Ships and Ocean Engineering (KRISO), and the two results agreed well. Zhou Li et al. built a series of models for ice breakage and accumulation at different heading angles (Zhou L et al, 2013, 2017, 2018). The ship resistance was compared to the test results and they exhibited a good agreement. Biao Su et al. studied the ship resistance and maneuverability in crushed ice area via a series of numerical simulations (Su B et al, 2010, 2011ab, 2014). Vroegrijk used STAR-CCM+ to study the navigation of ships in crushed ice channel based on DEM model (Vroegrijk et al, 2015). Ji S Y et al developed an improved DEM model to study the ice movement process and applied the method for investigations on ship-ice interaction in cold regions, and a series of research results were obtained. The model in their study was simplified and the ice model was set as discoid shape. The acting force between the ship model and 
ice was related to ice thickness and size, flow velocity, ice concentration (Ji S Y et al,2015). Kim J H et al used the finite element method to carry out a numerical simulation of an ice-going ship navigating through a broken ice field (Kim J H et al, 2019). Ningbo Zhang et al used Smoothed Particle Hydrodynamics (SPH) method to simulate the ice failure process and ice-ship interactions, but the inadequacy of the study was that the water phase is not included in the simulation (Zhang $\mathrm{N}$ et al, 2019). Bateman S P et al developed a technique using the discrete element method (DEM) to simulate the fracture mechanics of ice under flexural, compressive, and tensile loading (Bateman S P et al). Gong $\mathrm{H}$ et al studied the resistance of a ship in an unconsolidated ridge by using a three dimensional discrete element method. The ridge deformation is considered (Gong H et al, 2019) . Ranta $\mathbf{J}$ et al introduced a probabilistic limit load model, which can be used to analyze peak ice load events and to estimate the maximum peak ice load values on a wide, inclined, offshore structure. The study is based on the combined FEM-DEM simulations (Ranta $\mathrm{J}$ et al, 2019). Tuhkuri $\mathrm{J}$ et al gives a review of the use of DEM in studying ice-structure interaction before 2017. The development of DEM method and its application in ice mechanics are introduced in detail (Tuhkuri J et al, 2018).

In this study, Based on the STAR-CCM+ calculation program, a CFD-DEM coupling numerical computation method of ship hull-brash ice-fluid interaction is established by combining the modeling and simulation advantages of Euler and Lagrangian method in both the hydrodynamic and particle contact dynamic problem, and be applied to study the ship resistance of ship model in the brash ice channel. During the research, two typical ice particle shapes, tetrahedron and polyhedron, were selected according to the picture of brash ice in the HSVA ice towing tank. The numerical model of DEM ice particles was built by the experimental brash ice parameters, and the numerical ice channel was established by referring to the size and parameters of the ice channel in model test. Next, the influence of DEM ice particle shape on contact force and ship-ice interaction was studied. After that, the influence of the one-way coupling and two-way coupling computational scheme between fluid and particles on the calculation accuracy and the interaction phenomenon was studied and analyzed. Finally, the ship - ice interaction process and mechanical behavior of ship and particle interaction in the brash ice channel was simulated, and the numerical results were compared with the experiment of HSVA ice tank.

\section{Geometric Model}

A 76000DWT ice-strengthened Panama bulk carrier used as the numerical calculation model in this study is the same model in the HSVA model test, the model of this ship is shown in Fig. 1. Where, Fig.1 (a) is the side view of HSVA model, the model is a single-screw bulk carrier with bulbous bow and u-shaped stern, while Fig.1 (b) and (c) are the stem and stern view of the model. 


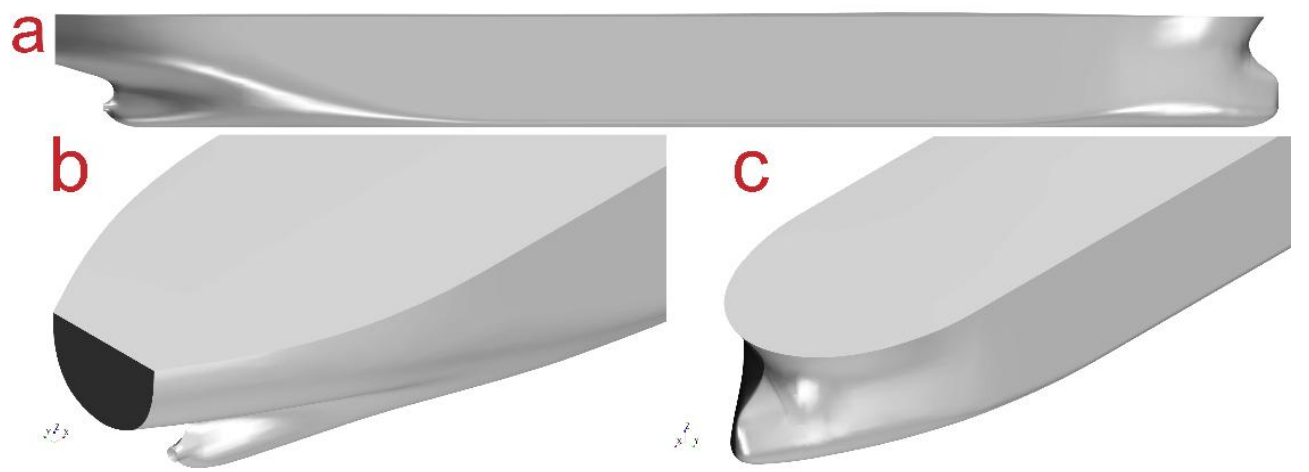

Fig. 1 Geometric model of the ship in numerical simulation. a. the side view of the HSVA model;b. the stem view of the HSVA model; c. the stern view of the HSVA model

The numerical calculation model in this paper is consistent with the HSVA model test, with a scale ratio of 30.682. The parameters of the numerical calculation are selected based on the experimental data of HSVA. The parameters of the ship model are shown in Table 1.

Table 1. Main parameters of the 76000 DWT ice-strengthened bulk carrier

\begin{tabular}{|c|c|c|c|}
\hline & $\begin{array}{l}\text { Ship } \\
\text { Scale }\end{array}$ & $\begin{array}{l}\text { HSVA } \\
\text { Model }\end{array}$ & $\begin{array}{c}\text { Numerical } \\
\text { calculation model }\end{array}$ \\
\hline Scale Ratio & 1 & & 30.682 \\
\hline Length between perpendiculars / $\mathrm{m}$ & 217 & 7.07 & 7.07 \\
\hline Width / m & 32.25 & 1.05 & 1.05 \\
\hline Depth / m & 20.1 & 0.65 & 0.65 \\
\hline Draft design / $\mathrm{m}$ & 12.4 & 0.40 & 0.40 \\
\hline Design speed in open water $\mathrm{m} / \mathrm{s}$ & $15 \mathrm{kn}$ & 1.39 & 1.39 \\
\hline Demand speed by Finnish-Swedish Ice Class Rules m/s & $5 \mathrm{kn}$ & 0.464 & 0.464 \\
\hline
\end{tabular}

\section{Numerical method of ship-ice-water based on CFD-DEM coupling}

\subsection{The governing equation of incompressible fluid in CFD-DEM coupling}

In the process of ship-ice-water interaction, the interaction between the fluid and discrete ice terms involves mechanical properties, heat transfer and exchange processes. This paper focuses on mechanical properties, ignores the heat transfer as well as exchange between discrete ice and fluid terms, while the motion of incompressible Newtonian fluid satisfies continuity equation and momentum conservation equation (Stephen B et al, 2010; NOROUZI H. et al, 2016):

$$
\begin{gathered}
\frac{\partial\left(\rho_{f} \varepsilon_{f}\right)}{\partial t}+\nabla \cdot\left(\rho_{f} \varepsilon_{f} \vec{u}\right)=0 \\
\frac{\partial\left(\rho_{f} \varepsilon_{f} \vec{u}\right)}{\partial t}+\nabla \cdot\left(\rho_{f} \varepsilon_{f} \vec{u} \cdot \vec{u}\right)=-\varepsilon_{f} \nabla p-\nabla \cdot\left(\varepsilon_{f} \vec{\tau}_{f}\right)+\rho_{f} \varepsilon_{f} \vec{g}-\vec{F}
\end{gathered}
$$

Where $\rho_{f}$ is the density of fluid term; while $\varepsilon_{f}$ is the volume fraction of the fluid term in the control volume. 
The relationship is that $\varepsilon_{f}=1-\varepsilon_{p}, \quad \varepsilon_{p}=\sum_{i=1}^{n_{p}} V_{p_{i}} / \Delta V$, where $\varepsilon_{p}$ is the volume integral number in the control volume for discrete ice term; $V_{p_{i}}$ and $\Delta V$ is the volume of discrete ice particles numbered $i$ and the total volume of the regional control volume, respectively; $\vec{u}$ is the average velocity of fluid; $p$ is the mean value of pressure; $\vec{F}$ is the volume average of the resistance of particles to the surrounding fluid in the discrete ice term of the control volume, including resistance, pressure gradient force, shear stress and other interaction forces between the fluid term and the discrete ice term. $\tau_{f}$ is the stress tensor of the fluid, and is expressed as:

$$
\overleftrightarrow{\tau_{f}}=-u_{f}\left(\nabla \vec{u}+(\nabla \vec{u})^{\prime}\right)+\frac{2}{3} \mu_{f}(\nabla \cdot \vec{u}) \overleftrightarrow{\delta}
$$

In the process of ship-ice-water interaction coupling, the average volume $\vec{F}$ of particles in the discrete ice term is expressed as:

$$
\vec{F}=\frac{1}{V_{\text {cell }}} \sum_{i=1}^{n_{p}} \overrightarrow{F_{i}}=\frac{1}{V_{\text {cell }}} \sum_{i=1}^{n_{p}}\left(\overrightarrow{F_{d i}}+\overrightarrow{F_{b i}}+\overrightarrow{F_{l i}}+\overrightarrow{F_{a i}}+\overrightarrow{F_{p i}}\right)
$$

Where $n_{p}$ is the number of discrete ice particles in each fluid control volume; $u_{f}$ is the dynamic viscous coefficient of fluid; $\vec{\delta}$ is unit tensor; $\overrightarrow{F_{d i}}, \overrightarrow{F_{b i}}, \overrightarrow{F_{l i}}, \overrightarrow{F_{a i}}$ and $\overrightarrow{F_{p i}}$ are the drag force, buoyancy force, lift force, additional mass force and pressure gradient force of the fluid term acting on the ice particles $i$ in the discrete ice term, respectively.

\subsection{The governing equation of discrete phase interaction in CFD-DEM coupling}

In the process of ship-ice-water interaction, discrete phase ice particles are solved by DEM method under the Lagrangian framework. The brash ice in the Lagrangian framework is composed of several basic composite DEM particles. The ship navigation process in brash ice channel is simulated through the interaction between DEM particles, wall, and ship hull. The motion of discrete DEM ice particles usually includes translational motion and rotational motion. The governing equations of motion based on Newton's second law are as follows (Siemens PLM, 2019).

Equations of translational motion and momentum conservation of ice particles in discrete phase:

$$
m_{i} \frac{d v_{i}}{d t}=\sum_{j} F_{i j}+F_{g}+F_{\text {fluid }}
$$

Angular momentum conservation equation of ice particles in rotation:

$$
\frac{d}{d t} I_{i} \omega_{i}=\sum_{j} T_{i j}
$$

Where $m_{i}, v_{i}$ and $\omega_{i}$ represent the mass, velocity and angular velocity of the discrete ice particles numbered $i$, 
respectively. While $I_{i}$ is the rotational inertia of particles numbered $i$. For spherical particles, $I_{i}=2 m_{i} R_{i}^{2} / 5$ where $R_{i}$ is the radius of particle $i . F_{g}=m_{i} g$ is the gravity of particle $i ; F_{\text {fluid }}$ is the force of fluid on particle $i ; F_{i j}$ is the collision force between particle $I$ and particle $J$ or the wall, and other non-contact forces acting on the particle. $T_{i j}$ is the contact moment, which represents the torque generated by the contact force on the particle except for its gravity. Moreover, $T_{i j}=r \times F_{i j}-\mu_{r}\left|F_{i j}\right| \omega_{i} /\left|\omega_{i}\right|$ and $r$ is the vector from the particle center of gravity to its contact point, and $u_{r}$ is the rolling coefficient of friction.

\subsection{Turbulence model and free-surface treatment}

The shear stress transport (SST) $k-\omega$ turbulence model (Menter F. R et al, 1994) is employed for numerical simulations, the VOF (Volume of Fluids) method with a High-Resolution Interface Capture (HRIC) scheme (Hirt C. W et al, 1981) is used to model the air-water two phase problem. A numerical wave beach (Choi J et al, 2009) with $l=1.5 \mathrm{Lpp}$ damping area was established at the inlet, side and outlet boundary of the tank to avoid any unphysical reflection.

\subsection{Contact Theory of Discrete Phase Ice Particles}

\subsubsection{Interactions between particle-particle and particle-wall in the brash ice channel}

The interaction of different phases in brash ice channel include DEM ice particles, solid wall and VOF phase. The relationship between various phases in brash ice channel is shown in Fig. 2. The object to be considered in the numerical calculation of ship resistance in the ice-breaking channel include ship hull, brash ice particle, ice level, brash ice channel and fluid medium. The ship hull is regarded as a rigid undeformed body. The brash ice particles are DEM particles with 6 degrees of freedom. In the calculation process, five types of ice-related interaction, including ship hull-brash ice, brash ice-brash ice, level ice-brash ice, brash ice-water, brash ice-air, ship hull-water and ship hull-air are considered.

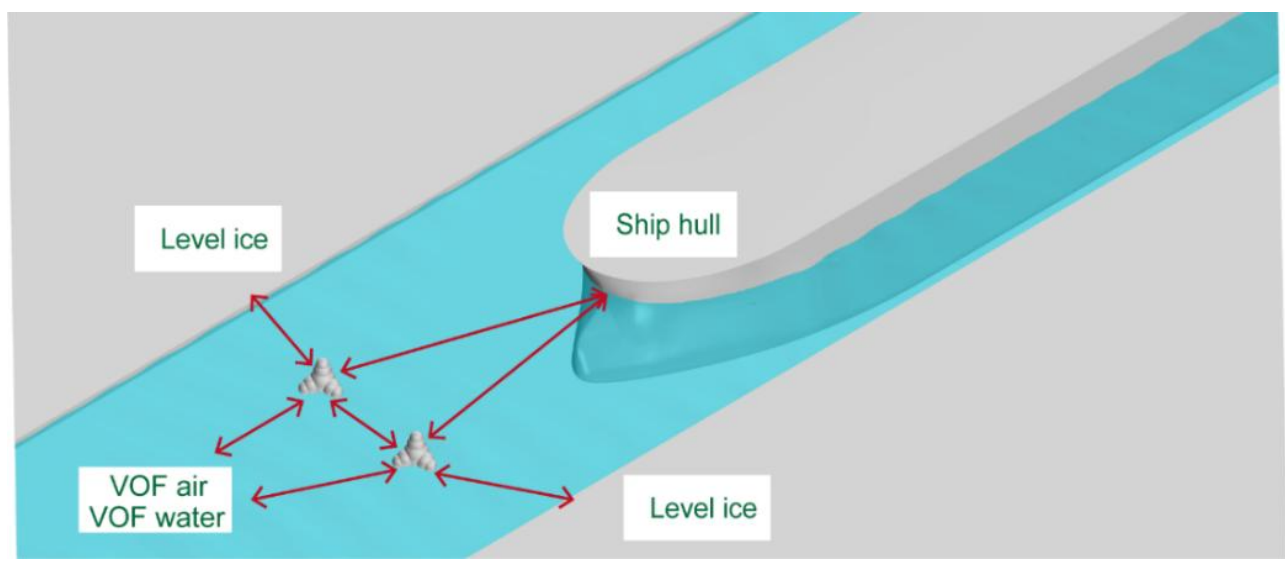

Fig.2 The relations between the interaction of items in brash ice channel and brash ice zone

\subsubsection{Particle-Particle and Particle-Wall interaction}


In physical reality, the ice crushing is an unneglected part in fluid-ice-structure interaction problem not only for pack ice (big ice piezes) condition but also for brash ice (small ice piezes) condition. The ice computational model that comprehensively considers the ice-ice physical interaction is the key and difficult point of the fluid-ice-structure interaction problem. We assume that the elastic contact of brash ice used in our study because we do not know any better way to do even though in reality the contact between two ice pieces is never elastic. In the simulation process with the elastic contact assumption of brash ice, the contact and collision between particles and particles, particles and wall (ship hull and level ice) are the inevitable results of particle movement. Therefore, in terms of contact stress, this study uses an efficient and accurate rigid body non-linear contact force modelHertz-Mindlin (Johnson, K.L, 1987; Di Renzo et al. 2005; Siemens PLM, 2019). For the unbreakable problems, the Hertz-Mindlin model shown in Fig. 3 is the most commonly used contact model in DEMs due to its efficient and accurate force calculation for two elastic bodies. The model is a variant of a non-linear spring-damped contact model based on Hertz-Mindlin contact theory.

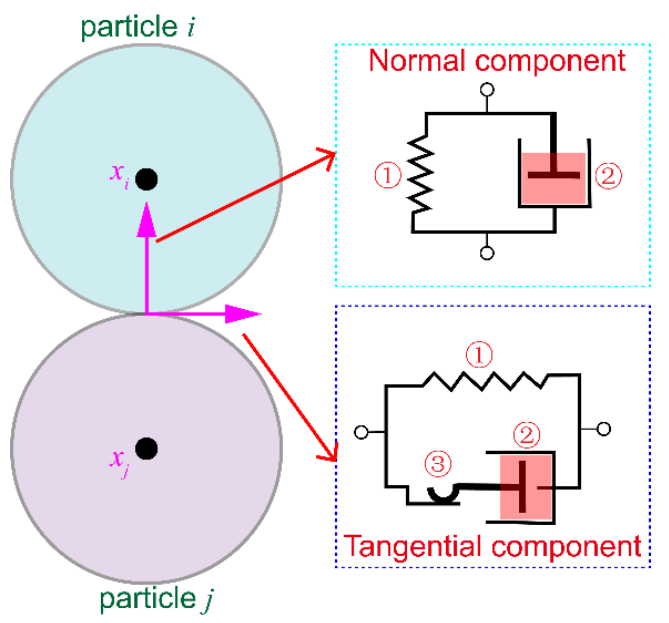

Fig.3 Hertz-Mindlin contact Model (1).Springs, (2).Dampers, (3).Graters

The forces between two spheres, $i$ and $j$, are described by the following set of equations.

$$
F_{\text {contact }}=F_{n i j}+F_{\text {tij }}
$$

In the formula, $F_{n i j}$ is the normal force and $F_{t i j}$ is the tangential force.

The expression of normal force $F_{n i j}$ is as follows:

$$
F_{n}=-K_{n} d_{n}-N_{n} v_{n}
$$

The tangential force $F_{t i j}$ is expressed as:

$$
F_{t}= \begin{cases}-K_{t} d_{t}-N_{t} v_{t} & \left(\left|K_{t} d_{t}\right|<\left|K_{n} d_{n}\right| C_{f s}\right) \\ \left|K_{n} d_{n}\right| C_{f s} d_{t} /\left|d_{t}\right| & \left(\left|K_{t} d_{t}\right|>\left|K_{n} d_{n}\right| C_{f s}\right)\end{cases}
$$

The normal spring stiffness $K_{n}$, normal damping $N_{n}$, normal damping coefficient $N_{\text {ndamp }}$, tangential spring 
stiffness $K_{t}$, tangential damping $N_{t}$, tangential damping coefficient $N_{\text {tdamp }}$ is defined respectively as:

$$
\begin{gathered}
K_{n}=\frac{4}{3} E_{e q} \sqrt{d_{n} R_{e q}}(10) ; N_{n}=\sqrt{\left(5 K_{n} M_{e q}\right)} N_{\text {ndamp }}(11) ; N_{\text {ndamp }}=-\ln \left(C_{\text {rrest }}\right) / \sqrt{\pi^{2}+\ln \left(C_{\text {nrest }}\right)^{2}}(12) ; \\
K_{t}=8 G_{e q} \sqrt{d_{n} R_{e q}}(13) ; \quad N_{t}=\sqrt{\left(5 K_{t} M_{e q}\right)} N_{\text {tdamp }}(14) ; N_{\text {tdamp }}=-\ln \left(C_{\text {trest }}\right) / \sqrt{\pi^{2}+\ln \left(C_{\text {trest }}\right)^{2}}(15) .
\end{gathered}
$$

Where, $R_{e q}$ is the equivalent radius, $R_{e q}=1 / \frac{1}{R_{i}}+\frac{1}{R_{j}} ; M_{e q}$ is the equivalent particle mass, $M_{e q}=1 / \frac{1}{M_{i}}+\frac{1}{M_{j}}$; $E_{e q}$ is the equivalent Young's modulus, $E_{e q}=1 / \frac{1-v_{i}^{2}}{E_{i}}+\frac{1-v_{j}^{2}}{E_{j}} ; G_{e q}$ is the equivalent shear modulus, $G_{e q}=1 / \frac{2\left(2-v_{i}\right)\left(1+v_{i}\right)}{E_{i}}+\frac{2\left(2-v_{j}\right)\left(1+v_{j}\right)}{E_{j}} ; M_{i}$ and $M_{j}$ are masses of sphere $i$ and sphere $j, d_{n}$ and $d_{t}$ are overlaps in the normal and tangential directions at the contact point, and the detailed description, definition and calculation of the normal overlap and tangential overlap can be found in the reference (Di Renzo et al. 2005), $R_{i}$ and $R_{j}$ are the radii of the spheres, $E_{i}$ and $E_{j}$ are Young's modulus of the spheres, $v_{i}$ and $v_{j}$ are the Poisson's ratios, $v_{n}$ and $v_{t}$ are the normal and tangential velocity components of the relative sphere surface velocity at the contact point, the values of which are given in section 4. $C_{\text {nrest }}$ and $C_{\text {trest }}$ are the normal and tangential coefficients of restitution, the values of which were set to 0.5 , and 0.5 , respectively, in this study. $C_{f s}$ is the coefficient of friction between particles. For particle-wall collisions, the formulas stay the same, but the wall radius and mass are assumed to be $R_{\text {wall }}=\infty$ and $M_{\text {wall }}=\infty$, so the equivalent radius is reduced to $R_{e q}=R_{\text {particle }}$ and equivalent mass to $M_{\text {wall }}=M_{\text {particle }}$.

\subsubsection{Fluid-particle interaction}

The interaction force of discrete element particles in the flow field mainly includes the buoyancy force $F_{b}$ of the particles, the resistance $F_{d}$ of the flow field to the particles, the additional mass force $F_{a}$ and the lift force $F_{l}$ of the particles. In this study, drag resistance $F_{d}$ and pressure gradient force $F_{p}$ (including buoyancy effect) are calculated. In the process of coupling calculation, the drag resistance of DEM particles is affected by the fluid viscosity. The drag resistance of DEM particles is often calculated by the drag coefficient. However, the drag coefficient of DEM particles is solved by choosing Hertz-Mindlin drag coefficients in this work, which are mainly determined by the Reynolds number and sphericity of particles and are mainly used for aspherical objects in light-loaded particle flow.

Resistance to particles:

$$
F_{d}=\frac{1}{2} C_{d} \rho A_{P}\left|\overrightarrow{v_{s}}\right| \overrightarrow{v_{s}}
$$

Resistance coefficient $C_{d}$ (Haider, A. and Levenspiel, O., 1989) :

$$
C_{d}=\frac{24}{\operatorname{Re}_{p}}\left(1+A \operatorname{Re}_{p}^{B}\right)+\frac{C}{\left(1+\frac{D}{R e_{p}}\right)}
$$


Where, $C_{d}$ is the drag coefficient of particles, $\rho$ is the density of fluid, and $v_{s}$ is the slip velocity of particles. $\overrightarrow{v_{s}}=\overrightarrow{v_{c}}-\overrightarrow{v_{d}}$, where, $\overrightarrow{v_{c}}$ is the water velocity, and $\overrightarrow{v_{d}}$ is the particle velocity; $A_{p}$ is the surface area of the composite particles, $R_{e p}$ is the Reynolds number of particles, wheile A, B, C and D are the coefficients of sphericity of particles, and they are set to $8.1716 e^{-4.0665 \phi}, 0.0964+0.5565 \phi, 73.690 e^{-5.0746 \phi}$ and $5.3780 e^{-6.2122 \phi}$ in current study, respectively, where $\phi$ is the particle sphericity.

DEM particles are subjected to pressure gradient force and additional mass force in addition to fluid resistance. The expressions of pressure gradient force and additional mass force are as follows;

The pressure gradient force is expressed as:

$$
F_{p}=-V_{p} \nabla p_{\text {static }}
$$

Where, $V_{p}$ is the volume of particles and $\nabla p_{\text {static }}$ is the gradient of static pressure in continuous phase.

\section{The experimental and numerical model of brash ice and brash ice channel}

In this section, the experimental and numerical model of brash ice and brash ice channel in CFD-DEM numerical study are carried out, including mainly the description of the test in the HSVA ice towing tank, the discrete phase DEM modeling of brash ice particles and the establishment of brash ice channel.

\subsection{Description of the test in the HSVA ice towing tank}

The total resistance of the 76000DWT ice-strengthened Panama bulk carrier model in brash ice channel was carried out in HSVA's large ice basin (78 m long, $10 \mathrm{~m}$ wide and $2.5 \mathrm{~m}$ deep) and used for validating the CFD-DEM simulations. During the resistance test the model is towed by the carriage at a constant speed, and the propulsion system is completely dismounted. The towing force is applied to the model via a $1.5 \mathrm{~m}$ long double-hinged towing rod and a load cell mounted at the bow of the model (see Fig.12 a,b and 15f). By this method the model is rigidly connected to the carriage only in longitudinal direction so that the model is practically free to move within the remaining 5 degrees of freedom. For four repetitions tests the speed control of the carriage was set to $0.464 \mathrm{~m} / \mathrm{s}$, corresponding to $5 \mathrm{kn}$, full scale. The brash ice channel and brash ice thickness in this test were prepared according to guidelines set up by the Finnish Maritime Administration (FMA). According to the Guidelines for the Verification of Ship's Performance for Ice Classes through Model Tests a friction coefficient of $f$ $=0.10$ is required since 20 December 2005 (Finnish-Swedish Ice Class Rules, 2005). In order to obtain the required friction coefficient between ice and hull (a friction coefficient of $f=0.10$ which corresponds well with the friction coefficient measured in full scale.), the model surface was repainted with a special paint composition at HSVA and the dynamic friction coefficient between ice and model surface was determined according to the recent ITTC Recommendations. 


\subsection{Modeling of DEM brash ice particles}

The establishment of the numerical discrete phase brash ice particles is based on the picture of brash ice in the HSVA ice towing tank. As can be seen from the image of the brash ice channel in the HSVA ice towing tank in Fig. 4a, the brash ice particles that make up the brash ice channel have different shapes. It is difficult to reproduce the shape, location and distribution characteristics of each piece of ice in numerical simulation (Seo D. C., and Pallard R. A., 2016). Therefore, the shapes of brash ice particles in the numerical simulation are represented by two geometric shapes, namely tetrahedral particles of isotropic and irregular polyhedral particles, according to the picture of brash ice in the HSVA ice towing tank. The numerical brash ice was treated as DEM composite particles composed of several basic spherical particles, which were generated by the combination of basic spherical particles through the given geometric shape. The numerical DEM brash ice particles are shown in Fig. 4b, c. According to the brash ice parameters in the experiment, the height of the composite brash ice particles is set to $46 \mathrm{~mm}$, and the diameter range of the basic spherical particles of the composite brash ice particles is $8-12 \mathrm{~mm}$. The ice density in the simulation was $0.917 \mathrm{~g} / \mathrm{cm}^{3}$, and the friction coefficient between hull and ice was 0.1(HSVA Report, 2012). Due to the Young's modulus, Poisson's ratio and coefficient of friction between ice - ice are not given in the experiment report. According to the relationship between the elastic modulus and Poisson's ratio of model-scale ice and that of full-scale ice is consistent (Timco, G. W, 1984): $E_{\text {fullscale }}=\lambda E_{\text {modlescale. }}$; $v_{\text {fullscale }}=\lambda v_{\text {modlescale }}$ Where $\lambda$ is the scale ratio, the scale ratio of the model in this paper is 30.682. The Young's modulus of full-scale ice is $9 \mathrm{GPa}$ and the Poisson's ratio $v=0.3$ (Timco, G.W.,2010; Vroegrijk, E, 2012),therefore the elastic modulus of model-scale ice is 293.33Mpa. The static friction coefficient between ice and ice is set to 0.1 , and the dynamic friction coefficient between ice and ice is set to 0.03 based on reference (Raymond A. Serway, 2018). DEM brash ice particle properties are defined in Lagrangian phase, and the injector is used to define the position and pattern of particles entering the fluid continuum. Each injector generates a new particle beam for a given Lagrangian phase and the injector type is chosen as the surface injector derived from the Part Injector in the simulation. 


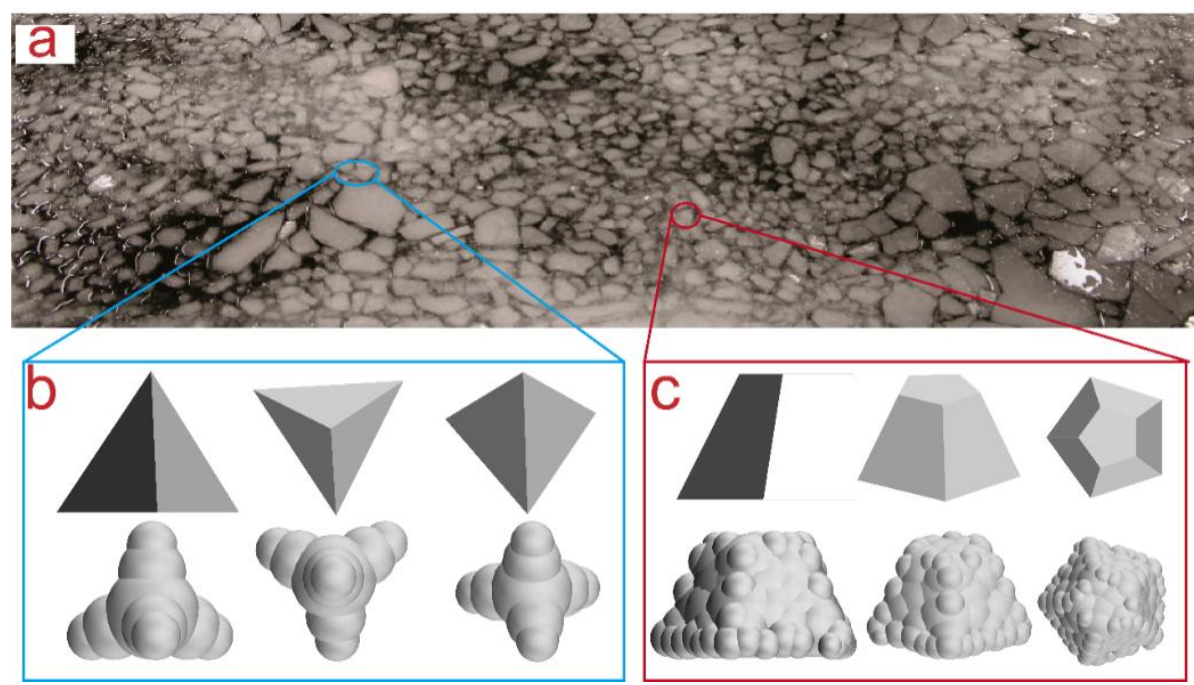

Fig.4 Brash ice particles of experimental and numerical brash ice channel. a. Distribution of the brash ice in HSVA ice tank; b. tetrahedral particles of isotropic brash particles; c. irregular polyhedral brash particles

4.3 Numerical brash ice channel model

The establishment of numerical brash ice channel is entirely based on the setting of the HSVA model test channel. The establishment of brash ice channel in the HSVA model test mainly includes: a) the establishment of ice level to meet the thickness requirements; b) cutting the area of brash ice channel to meet the width requirements; c) cutting the small pieces of brash ice to meet the requirements of brash ice channel, the cut brash ice particles after are shown in Fig. 5a; d) the compaction of brash ice channel to meet the specifications in accordance with the FINNISH-SWEDISH ICE CLASS RULES (Finnish-Swedish Ice Class Rules, 2005). The established ice channel is shown in Fig. 5a, c. The established numerical brash ice channel is shown in Fig. 5b, d, while the specifications of the numerical channel and the model test channel are the same. Brash ice channel is located in the middle of the width of the ice basin and flanked by level ice, the width of the brash ice channel is twice as wide as the beam of the vessel. 


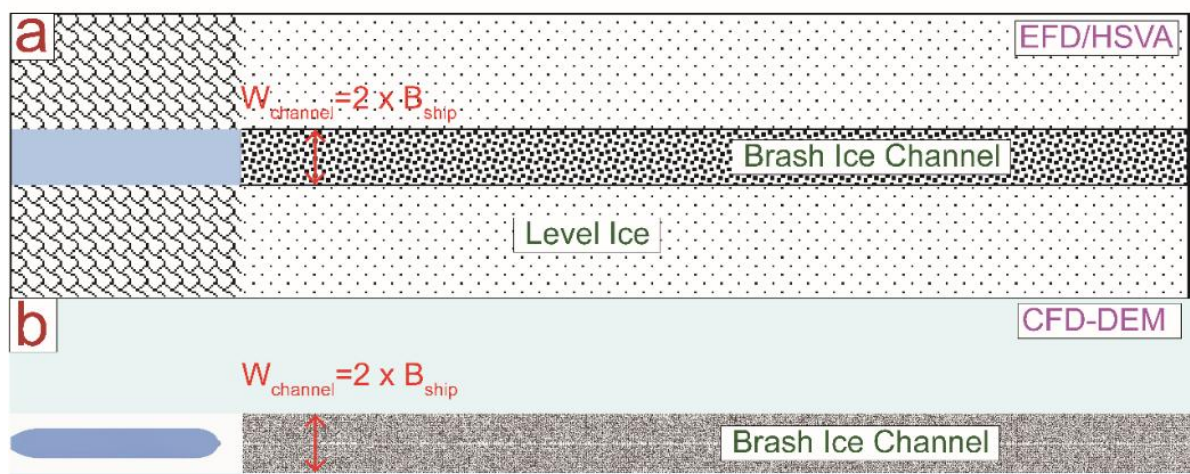

Level Ice

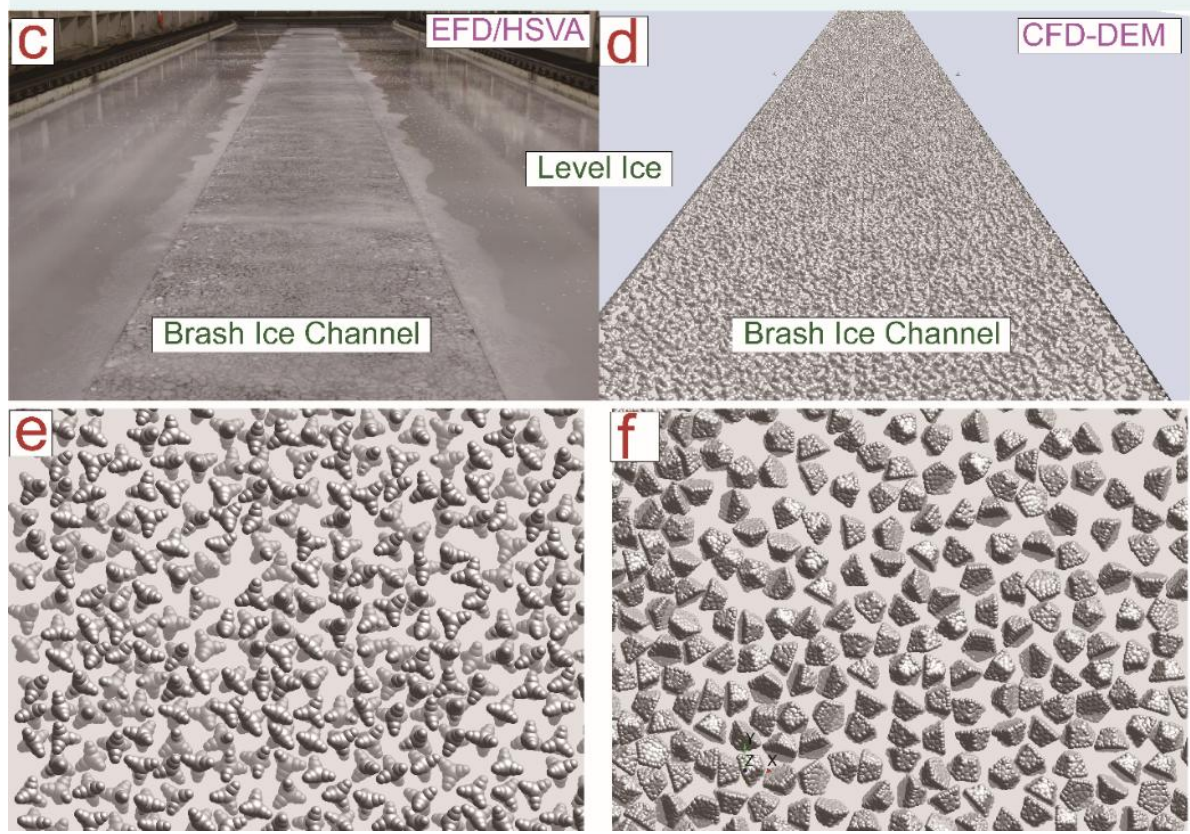

Fig.5 Brash ice channel of the HSVA test and numerical simulation. a and b. Schematic diagram of brash ice channel in HSVA ice basin and numerical simulation; $c$ and d Overall view of the brash channel in HSVA ice basin and numerical simulation; e and f. Distribution of brash ice particles in HSVA ice basin and numerical simulation

\section{Computational Domain, Boundary Conditions and Computational mesh}

The computational domain of brash ice channel is shown in Fig. 6, the Fig. 6a is the overall view of the computational domain, Fig. $6 \mathrm{~b}$ is the view of the velocity inlet boundary, Fig.6c is the view of the area near the hull model, including level ice, hull and free surface, etc., Fig. 6d is the view of the pressure outlet boundary. And the detailed boundary conditions are shown in Table 2 . The ship-ice-water interaction is symmetrical, therefore, the calculation model and calculation area are treated in half and the symmetrical plane is set in the mid-longitudinal section. To retain enough brash ice for interacting with the ship model, there is generation of enough brash ice in front of the transmission area of the ship model. The range of axial direction is $-2.25 L_{p p} \leqq x \leqq 8.0 L_{p p}$, the range of spanwise direction is $0.0 L_{p p} \leqq y \leqq 1.5 L_{p p}$, and the range of vertical direction is $-1.5 L_{p p} \leqq z \leqq 1.0 L_{p p}$. 


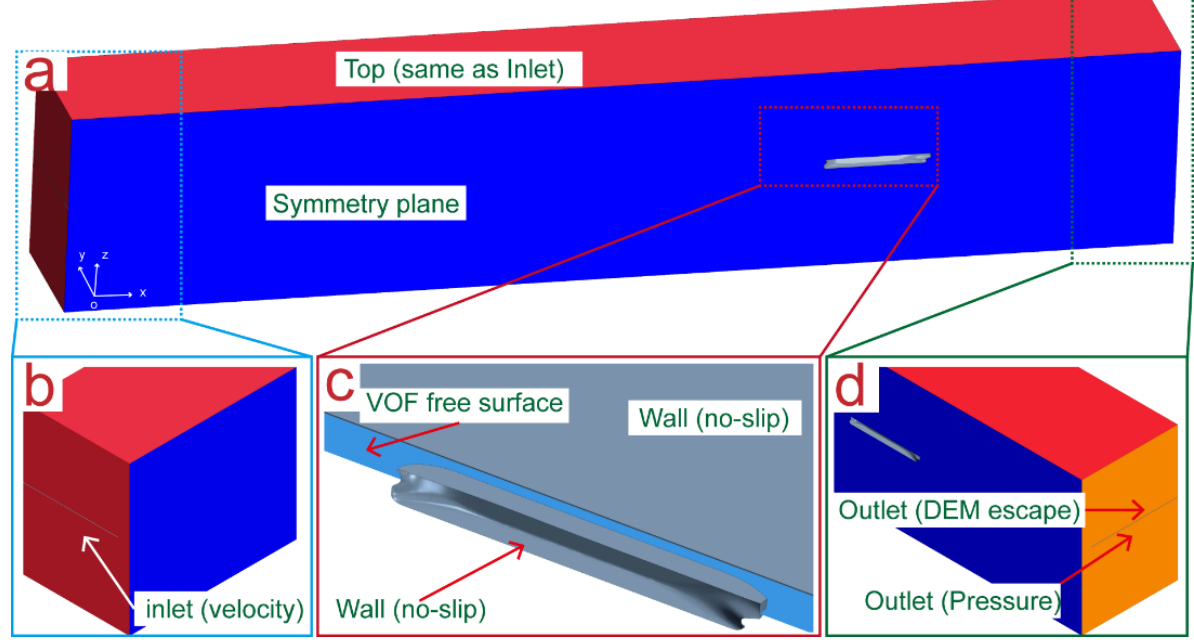

Fig.6 Computational domain of ship-ice-water numerical simulation. a. overall view of the computational domain; b. the view of velocity inlet boundary; c. the view of the area near the hull model; $7 \mathrm{~d}$. The view of the pressure outlet boundary

Table 2 Boundary conditions

\begin{tabular}{cc}
\hline Boundary & Boundary condition \\
\hline Inlet & Flat water surface based on VOF component of water and air Flat water surface \\
& velocity V = ship speed, turbulence intensity $=0.01$ \\
Outlet & Flat water surface based on VOF component of water and air; hydrodynamic \\
pressure on flat water surface; escape boundary of DEM brash ice particles & Sliding wall \\
Bottom & Sliding wall \\
Side & Non-slip wall, boundary conditions for DEM term \\
Ship & Non-slip wall \\
Level ice & Symmetric boundary \\
Symmetry & VOF free surface \\
Free surface & Particle surface injection conditions based on Part model \\
Inject face &
\end{tabular}

The trimmer mesh used in the simulation process is as shown in Fig. 7. For the free surface of the ship, the grid is densified around the hull and the stern area. A robust automated prism layer meshing algorithm is used to capture the boundary layer, with a two-layer all wall distance $(y+)$ treatment. The $y+$ values are kept in the 30-60 range. The smallest grid region in the fluid domain is the mesh refinement region of the free surface, and the corresponding grid resolution is $\Delta \mathrm{x}=25 \mathrm{~mm} . \Delta \mathrm{y}=25 \mathrm{~mm}, \Delta \mathrm{z}=12.5 \mathrm{~mm}$. For two-way coupling, the overall diameter of basic particles is smaller than the grid size of the free surface encryption area. In addition, the size of the grid in the boundary layer on the hull surface is sometimes smaller than the diameter of the particles. At this time, the source smoothing method is applied for two-way coupling correction. Therefore, the size of the grid and brash ice particles meet the requirements of two-way coupling calculation. Fig. 7a is the overall mesh. Fig. 7b, d are the mesh of the bow and the stern. Fig. $7 \mathrm{c}$ is the free surface and wall of ice level meshes. Fig. 7e, f are the 
Prismatic boundary layer mesh of the bow and the stern, respectively. The total number of computational grids is about 5.5 million.

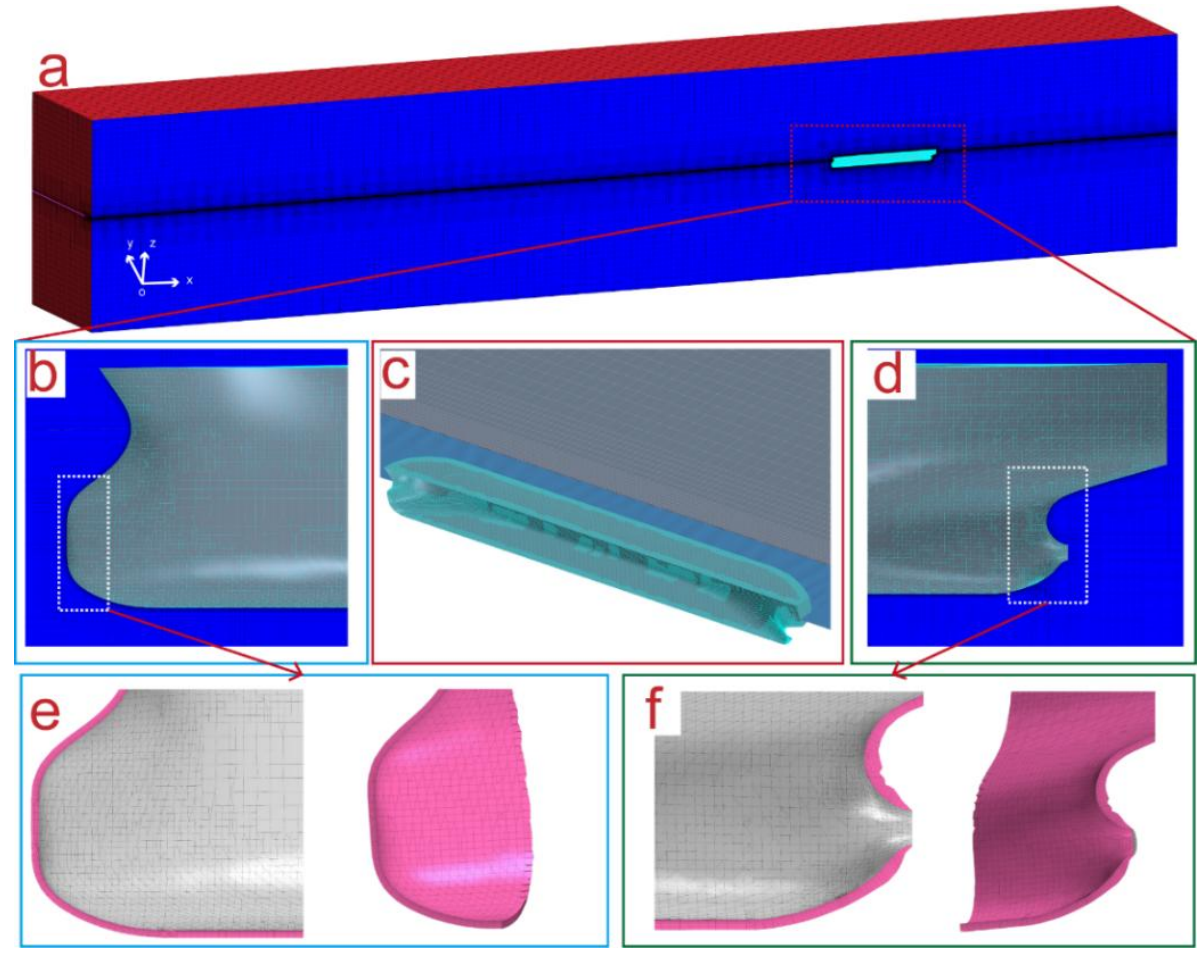

Fig.7 Computational mesh.a the overall mesh; b. the mesh of the bow; c. the mesh of free surface and wall of ice level; $d$ the mesh of the stern; e and f. the Prismatic boundary layer mesh of the bow and the stern,

\section{Verification of the numerical method}

For the validation of numerical models and methods of ship-water resistance, KCS (KRISO Container Ship-KCS), JBC (Japan Bulk Carrier-JBC) have been widely used by researchers to verify numerical models (Kim, W.J., 2001; NMRI, 2015). The computational strategy of numerical simulation of ship-water resistance in this paper is based on the author's long-term computational experience in relevant research. In the previous research, the author has applied KCS and JBC to verify the detailed numerical calculation method (Luo, W. Z., 2016; WU,T. C., 2017a b; Guo, C. Y., 2016). In addition, the 76K ice-strengthened Panama Bulk carrier used in this paper is the internal standard model that our team has studied extensively. For the limitation of the length and width of the towing tank in our laboratory, a series of hydrodynamic experiments (calm-water resistance test and PIV flow field measurement test) were carried out for the model with a scale ratio of 45. For the HSVA model test, only the data of total resistance including the brash ice contact force is available. On the basis of the previous validation of the numerical model for KCS and JBC ship models, the numerical model based on test data of the 76K ice-strengthened Panama Bulk carrier model with a scale ratio of 45 was validated. At $5 \mathrm{kn}$ speed, the total resistance of numerical calculation result is $1.90 \mathrm{~N}$, and the test results of Harbin Engineering University towing tank lab is $1.86 \mathrm{~N}$, with an error of $2.15 \%$; At the design speed of $15 \mathrm{kn}$, the total resistance of numerical 
calculation result is $15.94 \mathrm{~N}$, and the test results of Harbin Engineering University towing tank lab is $15.48 \mathrm{~N}$, with an error of $2.97 \%$. The verification of the flow field is described in the author's paper (WU,T. C., 2017c; Guo, C. Y., 2018).

For the validation of the contact model of DEM ice particles, it is difficult to validate the model precisely because there is no available contact test data for individual ice particles. The results of this paper can be used as a corresponding validation. The results show that the contact force model and brash ice model are reasonable. The contact force model applied in this paper is Hertz-Mindlin model. Hertz-Mindlin model is the most commonly used contact model in DEM due to its efficient and accurate force calculation for two elastic bodies. Hertz-Mindlin model was been used to solve the contact force between the structure and ice in the references (Sorsimo, A., 2019; Morgan, D., 2015; Seo, D. C., 2016). In addition, Hertz-Mindlin model is also used to calculate the contact force in the mainstream DEM and CFD-DEM commercial and open-source software, such as EDEM, LIGGGHTS and so on. It shows that Hertz-Mindlin model has good contact force calculation ability and effect, and is generally accepted and recognized.

\section{Influence of ice particle shape on ship-ice interaction}

In order to compare the influence of different ice particle shapes on the ship-ice interaction process, the tetrahedral shape and polyhedron shape ice particles are used in the two comparative simulation cases. In the following section, tetrahedral shape ice particles are called ICE-1, polyhedron shape ice particles are called ICE-2, the camera viewpoint underwater and above the water of the experimental and numerical ship-ice interaction are shown in Fig. 8 and 9. Fig. 8 is the experimental and numerical ship-ice interaction phenomenon from the camera viewpoint above the water. Among them, Fig. 8a is the side view of the interaction phenomena between ship hull and brash ice, the phenomenon of brash ice sliding along the side of the ship can be clearly observed, and the numerical calculation agrees well with the experimental phenomena in both ice shape. From the bow view (see Fig. 8b), brash ice piling up can be obviously observed. After navigating in the brash ice channel, the brash ice is discharged by the hull to both sides forming an open channel slightly smaller than the ship width. The brash ice sliding along the side to the stern gradually gathers in the middle under the action of the wake. It is worth noting that compared with the numerical results with symmetry, Fig. $8 \mathrm{c}$ in the photograph seems during the actual tests shows an uneven distribution of the brash ice in the channel. Because of the number and size of ice particles, and the distribution of ice on both sides of the ship hull cannot be completely consistent in the model test. In contrast, the CFD simulation is theoretical, because of the symmetry of the grid and the brash ice channel is also symmetrically generated. It is difficult to make the size and distribution of particles exactly consistent with the brash ice channel in the model test. The asymmetric distribution of ice particles may have a very small quantitative 
effect but does not affect the overall evolution.
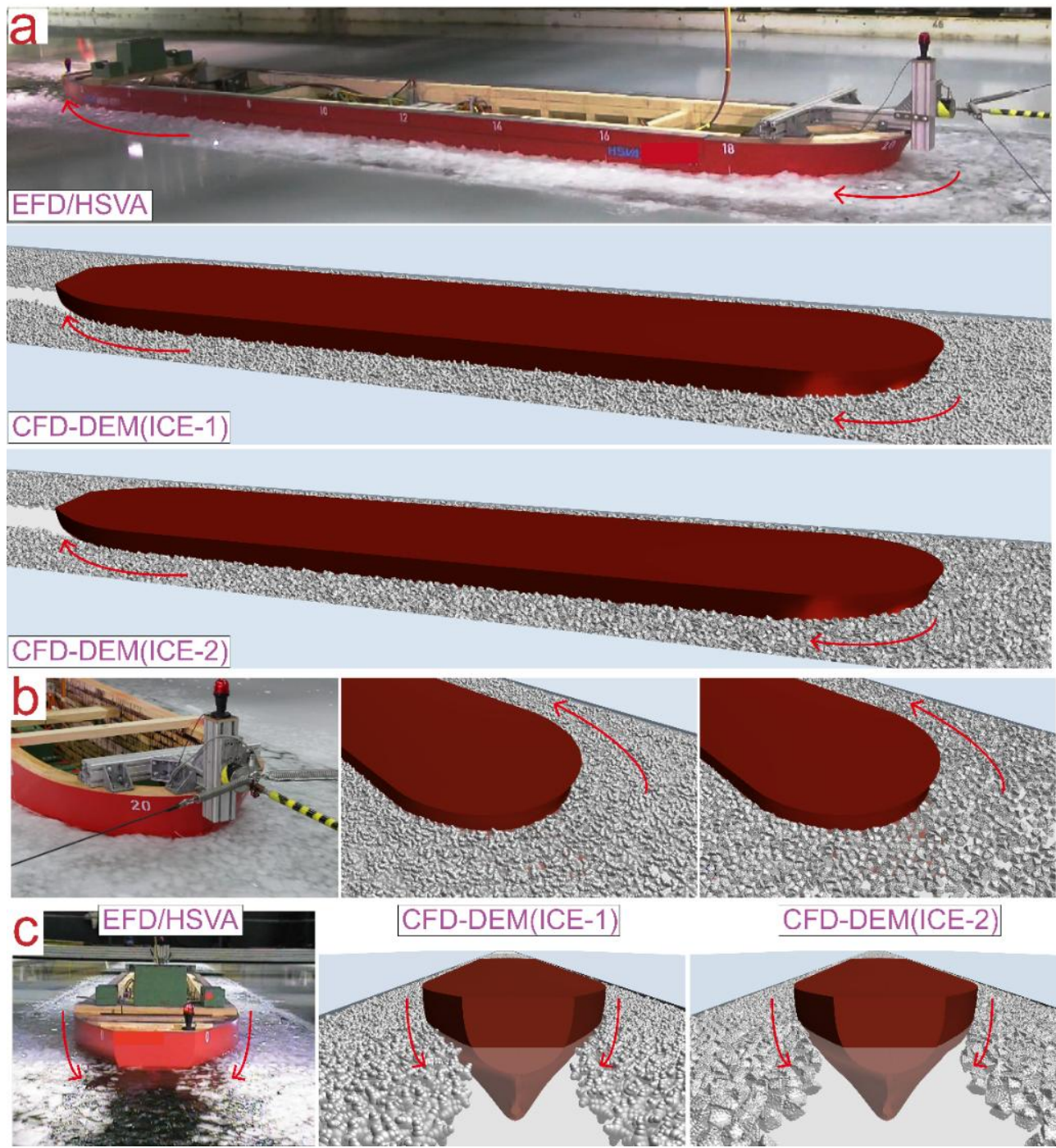

Fig 8 The view above the water of the experimental and numerical ship-ice interaction phenomenon. a. the side view of the interaction phenomena between ship hull and brash ice; $b$. the bow view of the interaction phenomena between bow and brash ice; c. the stern view of the interaction phenomena between stern and brash ice.

Fig. 9 shows the interaction phenomena between ship bow and brash ice from the perspective of underwater camera. Fig. 9a and 9b show the phenomena of ship-brash ice interaction from two underwater perspectives. Compared with the model test video, the interation process are almost the same with two brash ice shape. By comparing two different shapes of ice particles, it is found that the ICE-1 is more meticulous in capturing phenomena. The sharp profile of ICE-1 is closer to that of model test ice particles and the similarity of experimental phenomena is much closer to ICE-1. 
Fig 9 Two underwater views of ship-ice interaction phenomenon. a. the phenomena of ship-brash ice interaction from underwater upward view; b. the phenomena of ship-brash ice interaction from side underwater view.

The resistance curves in the ship-ice-water interaction process in brash ice channel is shown in Fig.10 (ICE-1) and Fig.11 (ICE-2), Where, the red curve is contact force between ship and brash ice, the green curve is ship water resistance, and the black curve is total resistance of ship - ice - water interaction. The total resistance curve of ICE-1 and ICE-2 are shown in Fig. 10b and Fig. 11b, respectively. The general trend of total resistance curve is consistent with the contact force curve. The collision between the ship and ice is one of the reasons for the increase of resistance value. In the early stage of entering the brash ice channel, only a part of the ship hull is in the brash ice channel. When the ship fully enters the brash ice channel, more brash ice is squeezed near the ship hull by the boundary between the ship and the channel. The friction and collision between a large number of brash ice and the ship hull leads to an increase in the total resistance, and the resistance value gradually becomes steady at about $16 \mathrm{~s}$.

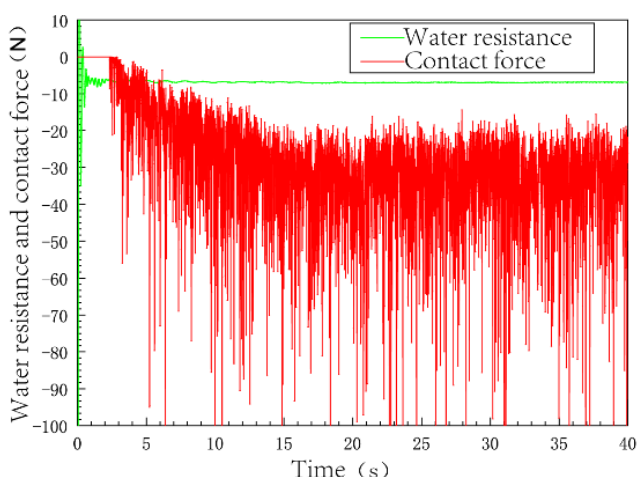

(a) Contact force and water resistance

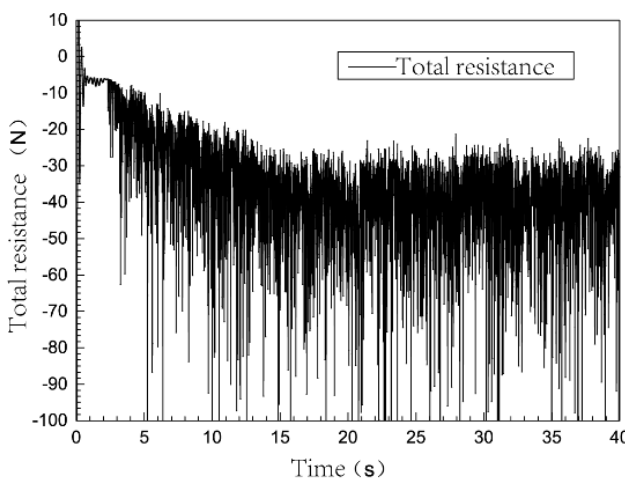

(b) Total resistance in brash ice channel Fig. 10 The resistance curves of ice- going ship in brash ice channel with ICE-1 


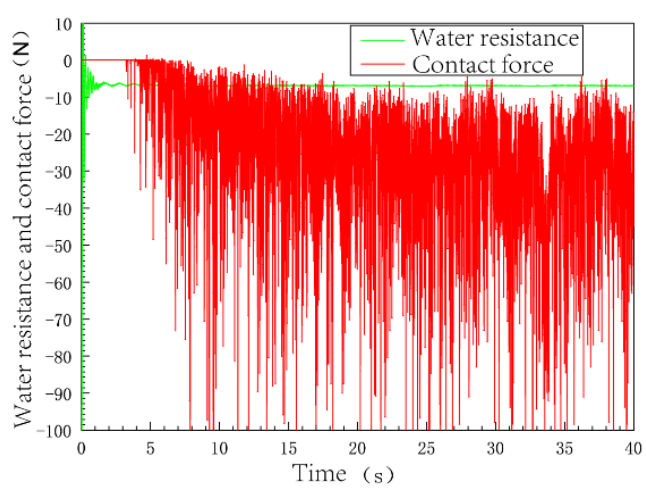

(a) Contact force and water resistance

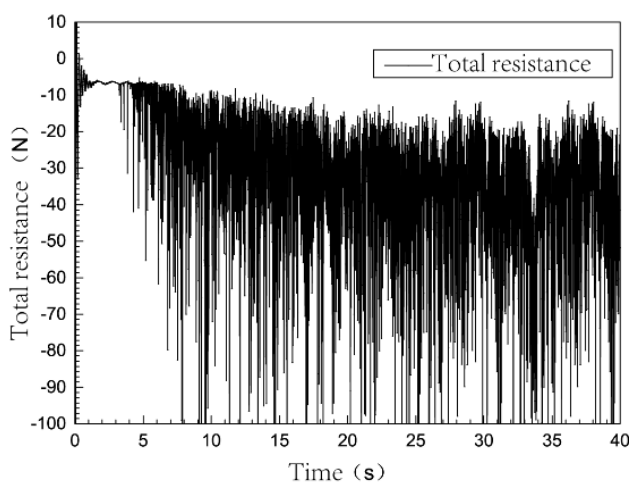

(b) Total resistance in brash ice channel

Fig. 11 The resistance curves of ice- going ship in brash ice channel with ICE-2

In this study, the experimental values of resistance in brash ice channel are obtained from the test in HSVA. Every ship speed condition conducted four test runs and the average of four test run results is taken as the final result. It would be ideal to directly compare the time history resistance from the tests and the simulation in the same figures, but since the data available is limited, the numerical model was verified using the mean value data derived from the ice resistance test. The parameters and test results of four groups of ice resistance tests in HSVA are compared with those calculated in this work, as shown in Table 3. The calculation results with ICE-1 compared with HSVA test is that the maximum error between the calculated and experimental values is $9.98 \%$, the minimum error is $-1.78 \%$, and the average error is $5.03 \%$. The water resistance in ship-water interaction is $6.90 \mathrm{~N}$, accounting for $16.4 \%$ of the total numerical resistance. Without considering the ship-water interaction resistance, the maximum error of ice resistance in DEM method is $18 \%$, the minimum error is $-8.1 \%$ and the average error is $-12.2 \%$. The calculation results with ICE-2 compared with HSVA test is that the maximum error between the calculated and experimental values is $-13.2 \%$, the minimum error is $-2.83 \%$, and the average error is $7.21 \%$. The water resistance in ship-water interaction is $6.93 \mathrm{~N}$, accounting for $18.69 \%$ of the total numerical resistance. Without considering the ship-water interaction resistance, the maximum error of ice resistance in DEM method is $-29.4 \%$, the minimum error is $-20.9 \%$ and the average error is $-24.5 \%$. Therefore, considering ship-water interaction, the CFD-DEM coupling method can take into account the resistance components of ship-water interaction and improve the calculation accuracy.

Table 3 Comparison of model test results and simulation results a. comparison of ICE-1

\begin{tabular}{ccccccc}
\hline & Ice & Resistance- & Average \\
NO. & $\begin{array}{c}\text { thickness-EFD/ } \\
\mathrm{mm}\end{array}$ & $\begin{array}{c}\text { Resistance } \\
\text { EFD/ N }\end{array}$ & $\begin{array}{c}\text { Error } \\
\text { Resistance EFD/ N }\end{array}$ & $\begin{array}{c}\text { Average error } \\
\text { CFD-DEM/ N }\end{array}$ & /\% & / \% \\
\hline 1 & 44.93 & 38.15 & & & 9.98 & \\
2 & 46.69 & 40.18 & 39.95 & 41.96 & 4.43 & 5.03 \\
3 & 45.12 & 42.72 & & & -1.78 & \\
\hline
\end{tabular}


b. comparison of ICE-2

\begin{tabular}{ccccccc}
\hline & Ice & Resistance & Average & Resistance \\
NO. & $\begin{array}{c}\text { thickness-EFD/ } \\
\mathrm{mm}\end{array}$ & $\begin{array}{c}\text { EFD/ N } \\
\text { Resistance EFD/ N }\end{array}$ & $\begin{array}{c}\text { Average error } \\
\text { CFD-DEM/ N }\end{array}$ & / \% & / \% \\
\hline 1 & 44.93 & 38.15 & & & -2.83 & \\
2 & 46.69 & 40.18 & 39.95 & 37.07 & -7.74 & -7.21 \\
3 & 45.12 & 42.72 & & & -13.2 & \\
4 & 46.37 & 38.75 & & & -4.33 & \\
\hline
\end{tabular}

By comparison of the simulation results in both ICE-1 and ICE-2 ice shape condition with HSVA test results, it is shown that the CFD-DEM coupling method can improve the calculation accuracy by considering the ship-water interaction resistance. The ICE-1 ice shape simulation result is better than ICE-2 in the maximum error, the minimum error and the average error. Therefore, ICE-1 ice shape is more recommended in CFD-DEM calculation from the perspective of resistance prediction.

\section{Influence of one-way and two-way coupling simulation}

In order to compare the influence of coupling schemes on the ship-ice interaction process, the one-way and two-way coupling schemes are used in the two comparative simulation cases. In a one-way coupled simulation, momentum and energy calculated by CFD are transferred from the fluid onto the particles, at the same time, the particles do not feed anything back onto the fluid and the influence of the interaction between ice particles and the fluid is neglected. In the process of two-way coupled simulation, particles move by the action of fluid, and the motion of particles also affects the flow of fluid, causing the fluid to flow around the particles. At the same time, the flow of fluid impacts on the particles, affecting their trajectory, thus the whole coupling process is two-way which causes the exchange of mass, momentum and energy between the particles and fluid phases.

The free surface waveform and velocity distribution of brash ice particles around ship hull in brash ice channel based on one-way and two-way coupling are shown in Figs.12 and 13, respectively. 
Fig. 12 Free surface waveform of ice-going ship in brash ice channel based on one-way and two-way coupling a. the global view of the waveform; b. the close-up view of the waveform around the stern; $b$. the close-up view of the waveform around the bow.

As the free surface waveform is shown in Fig.12, the contours of free surface waveforms of one-way and two-way coupling are basically the same. In the two-way coupling simulation, the interaction between the free surface and ice particles results in damping effects on the free surface waveform. Therefore, the free surface waveform of two-way coupling is more disordered than that of one-way coupling. As shown in Fig.13, the wake width of one-way and two-way coupling in brash ice channel is basically the same, but the velocity distribution of brash ice particles around ship hull is drastically different. In the two-way coupling simulation, the ice particles are affected by the flow field around the ship and cause a velocity decrease near the hull. Compared with one-way coupling, Two-way coupling simulation can give a better result for the structure-ice-water interaction with serious influence of the flow field on brash-ice behaviour.

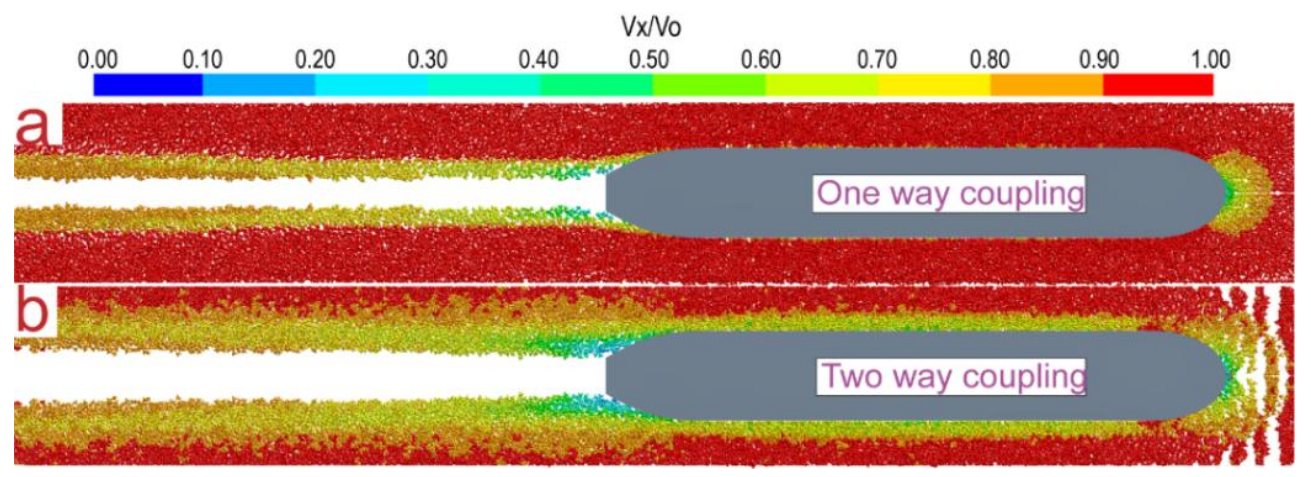

Fig.13 The velocity distribution of brash ice particles around ship hull of one-way and two-way coupling. a. one way coupling case; b. two way coupling case.

The total resistance curves with ICE-1 in one-way and two-way coupling are in Fig.14. The trend of resistance in one-way and two-way coupling is generally the same and the resistance value gradually becomes steady both at 
16s. The main difference is that the peak burr of two-way coupling is slightly weaker than that of one-way coupling. This is because the collision motion of ice particles in the two-way coupling process is mitigated by the fluid, which reduces the transient impact velocity and thus reduces the impact peak value. In one-way coupling, the maximum error between the calculated and experimental values is $9.98 \%$, the minimum error is $-1.78 \%$, and the average error is $5.03 \%$. In two-way coupling, the maximum error between the calculated and experimental values is $11.37 \%$, the minimum error is $-0.76 \%$, and the average error is $-5.23 \%$. In two-way coupling, the minimum error is better than one-way coupling. In actual condition, the interaction between ship-ice-water is two-way coupling, but the two-way coupling computing in CFD-DEM will occupy more computing resources than one-way coupling. For a low-speed simulation condition, the disturbance of the flow field and the two-way coupling effect between fluid and brash particles is not very significant, the one-way coupling is recommended for the less influential CFD-DEM case, resulting in the same calculation effect as two-way coupling at lower calculation cost. Therefore, the analysis of the results below is based on one-way coupling.

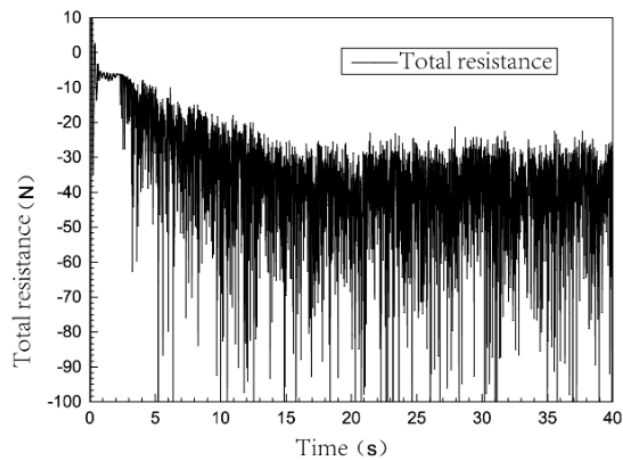

One-way coupling

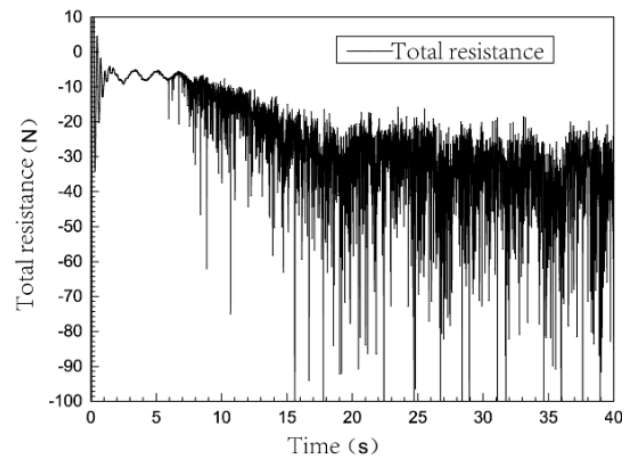

Two-way coupling

Fig 14 The total resistance curves with ICE-1. left. one way coupling case; right. two way coupling case.

\section{Analysis of ship-brash ice interaction process}

Detailed studies of ship-brash ice processes in the brash ice channel base on CFD-DEM are carried out in this section, the ship-brash ice interaction process is shown in Fig.15 under different sailing positions along the brash ice channel. 
Fig.15 The interaction between ice and ice-going ship in the brash ice channel at different ship positions. a, b, c, d and e. the typical time images of the ship gradually entering the brash ice channel; $f$. the bow view of experimental image; g. the stern view of experimental image.

Fig. 15 a, b, c, d, e are typical time images of the ship gradually entering the brash ice channel until the ship is fully sailing to the brash ice channel. Fig. $15 \mathrm{f}$, g shows that experimental image in ice tank. During the interaction process of ship and brash ice, a large amount of brash ice particles accumulate in the bow region. Some brash ice particles slide along both sides of the ship toward the stern of ship. The brash ice near the bow and both sides of ship slides slowly due to the adhesion forces between ship and brash ice. During the sliding process, the brash ice particles overturn and accumulate as they collide with each other. Area A (labeled A in Fig.15a, b, c, d, f) is the brash ice accumulation area at the bow of ship. Area B (labeled B in Fig.15 b, c, d, f, and g) is where brash ice accumulates on the ship side. As the ship enters the brash ice channel, the brash ice sails toward the stern of the ship along the line between the ship and level ice. Due to friction between the level ice and the ship hull, the brash ice acquires a semi-elliptical distribution, as shown by mark C in Fig.15a, b. After the ship has completely entered the brash ice channel, the brash ice on both sides of the brash ice channel gradually gathers in the middle under the action of the ice flow field at the stern of the ship, which is consistent with the model test results. Area D (labeled D 
in Fig.15e, g) is the brash ice gathering area at the stern of the ship.

The dimensionless velocity Vx/V0 distribution of brash ice particles in the channel is described in Fig. 16.

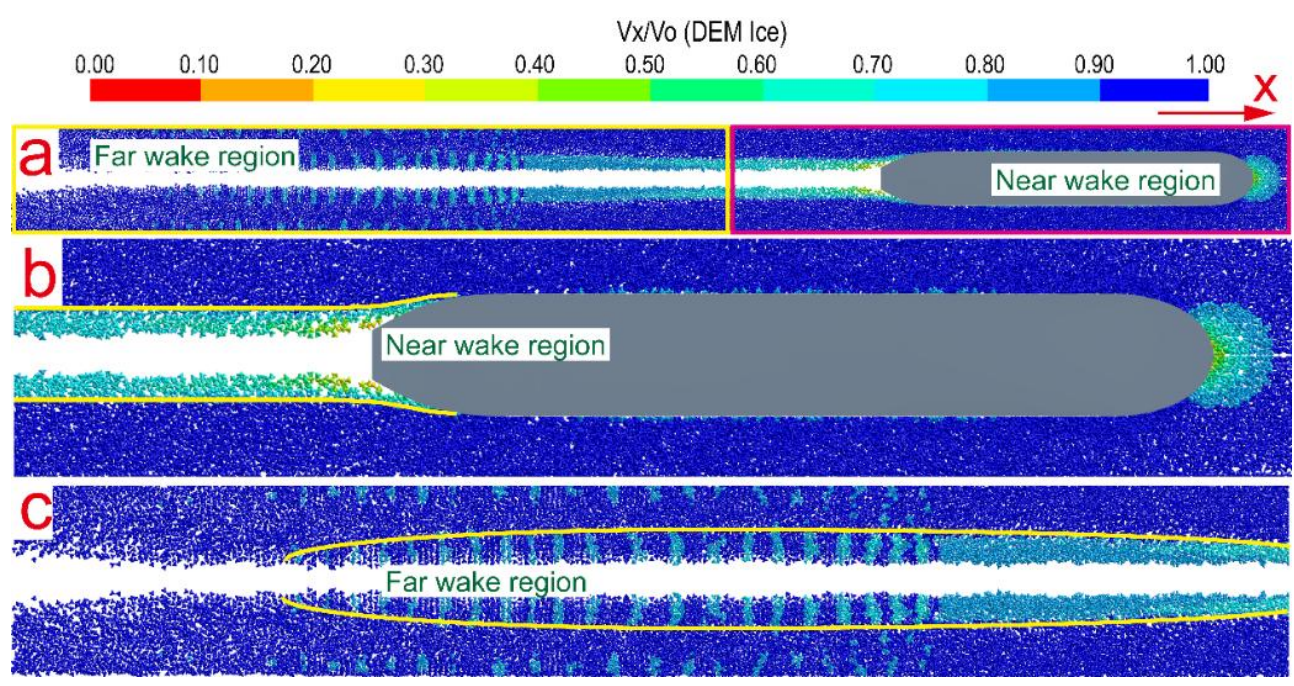

Fig. 16 The ice wake after the interaction between ship and brash ice in brash ice channel. a. the ice wake in the whole region; b. the ice wake in the near field; c. the ice wake in the far field.

Fig. 16a shows the ice wake in the whole region, As shown in Fig. 16a, the width of ice wake remains relatively unchanged in the whole area, and as the wake area gradually moves away from the ship hull, the wake velocity distribution is weakened by the wake effect of the hull. Fig. 14b shows the ice wake in the near field. The velocity of the brash ice decreases gradually after the interaction of ship and brash ice, and a stable band range exists in the wake region (yellow line envelope area in Fig. 16b). Fig. $16 \mathrm{c}$ shows the ice wake in the far field which indicates that the ice particles are no longer influenced by sustained ship hull shear, and the source of velocity reduction disappears due to the separation of ice particles from the frictional action of the ship hull. The brash ice is sheared by the other brash ice with far-field velocity, after which it gradually recovers to the far-field velocity. The velocity recovery process is in the radian band range (the yellow envelope region in Fig. 16c).

The angular velocity distribution of brash ice in the brash ice channel is shown in Fig.17, in which Fig.17a displays the whole field, Fig.17b shows the local enlargement of the stern area and Fig. 17c is the local enlargement of the bow area. From Fig. 17b, it can be observed that the ice particles have obvious angular velocity distribution at the position away from the stern of the ship, and within the wake range. There are also many particle rotations near the center of the channel. Fig. 17c shows the angular velocity distribution of particles in the process of interaction between brash ice particles and the bow region, which further confirms the description of the interaction phenomena of brash ice particles in Fig.8, 15 and 16. 
Fig.17 Angular velocity of brash ice particle in brash ice channel. a. the angular velocity distribution of brash ice in the whole region; $b$. the local enlargement of the angular velocity distribution of brash ice in the stern area; $c$. the local enlargement of the angular velocity distribution of brash ice in the bow area.

\section{Analysis of Mechanical Behavior of Ship and Particle Interaction in brash ice Channel}

Detailed studies of mechanical behavior of ship and particle interaction in the brash ice channel base on CFD-DEM are carried out in this section, and it mainly includes two parts: contact force and drag forces analysis between brash ice particles and ship. The distribution of contact forces between brash ice particles and ship interaction in brash ice channel is shown in Fig.18 and 19. Fig. 18 shows the distribution of magnitude of contact forces, from Fig. 18, it can be noted that the contact processes of ice particles such as collision and extrusion mainly occur in the areas of bow contact, level ice interaction with ship hull and in the wake of ice particles at stern and near field. The area around the ship hull is the main region where the interaction of ice particles is relatively significant.

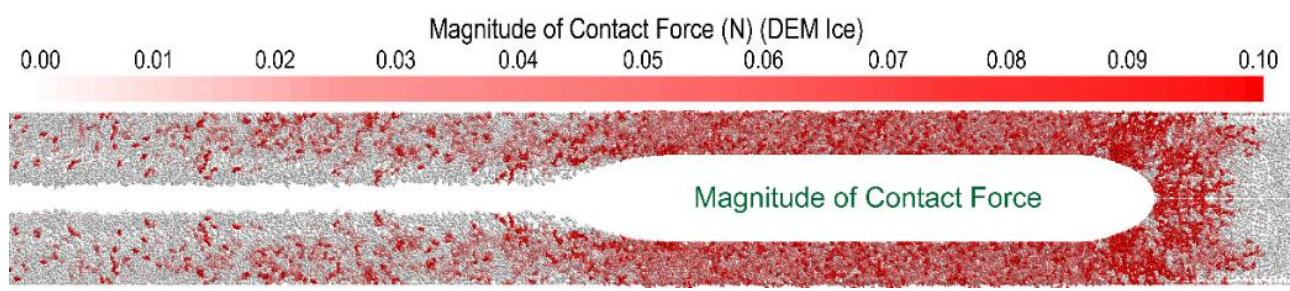

Fig. 18 Contact force of brash ice in the brash ice channel 


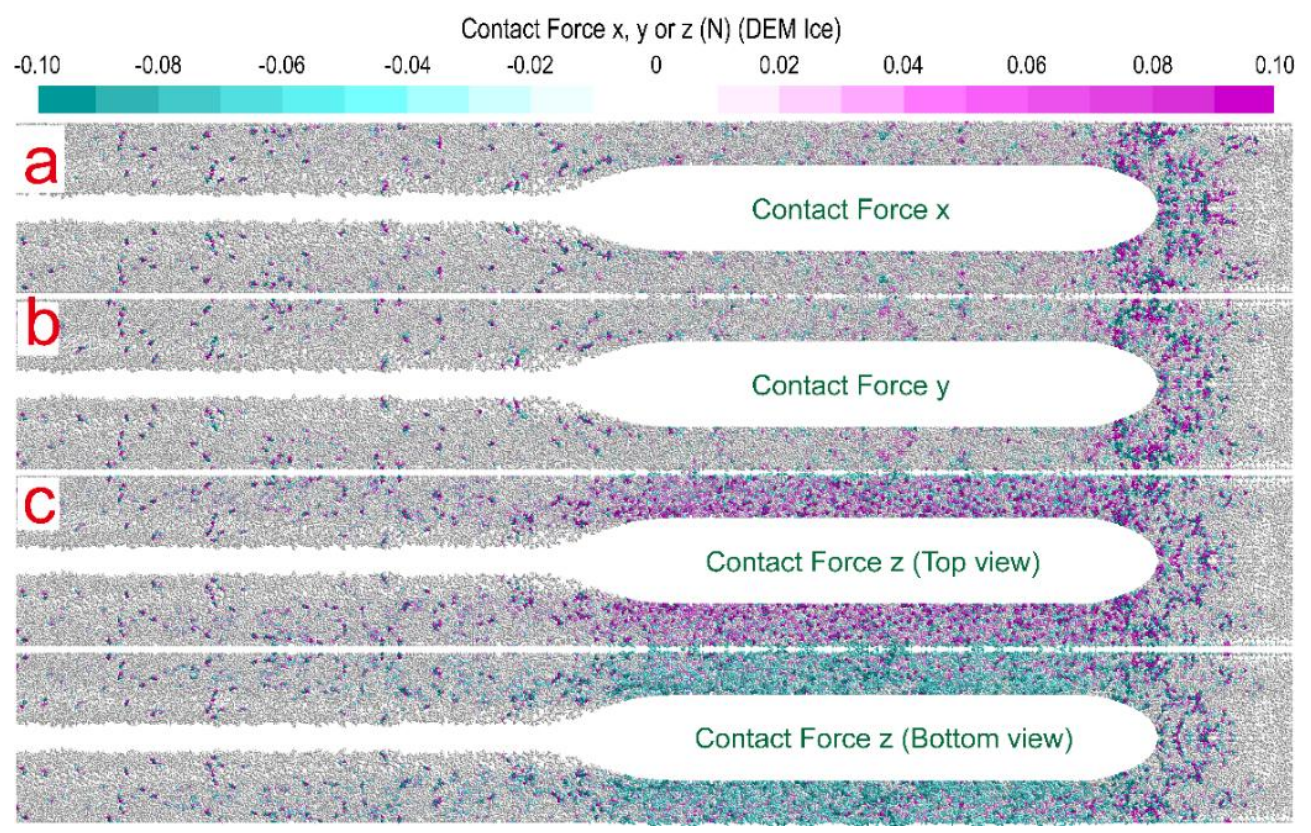

Fig. 19 Contact force $\mathrm{x}, \mathrm{y}$ and $\mathrm{z}$ of brash ice in brash ice channel. a. the distribution of axial contact force; $\mathrm{b}$. the distribution of spanwise contact force; c. the distribution of vertical contact force (Up. top view; Under. botton view).

Fig. 19a, b, c shows the distribution of axial, spanwise and vertical contact forces between brash ice particles in brash ice channel, respectively. From Fig. 19a, b, it can be seen that during the interaction between ice particles and bow, ice particles are impacted axially and extruded at span. This creates a significant contact force at axial and spanwise of brash ice near the bow, this is also the main contribution of ship-ice contact force (see Fig.10). Fig.19c demonstrates that the distribution of vertical contact force between the ice particles and the hull is basically the same as that shown in Fig. 18. This is due to the vertical contact between the particles during the movement of brash ice particles from the bow to the stern of the ship.

The distribution of drag forces between brash ice particles and ship in brash ice channel is shown in Figs.20 and 21. It can be observed that the distribution area of drag force between brash ice particles and ship is mainly concentrated in the bow, around the hull and the wake area, this is because the above region has a large velocity gradient and particle action degree. On further observation, it is found that the region of the bow has the greatest drag force, and the main areas of collision and extrusion between the ship and brash ice particles correspond to the area with the greatest drag force.

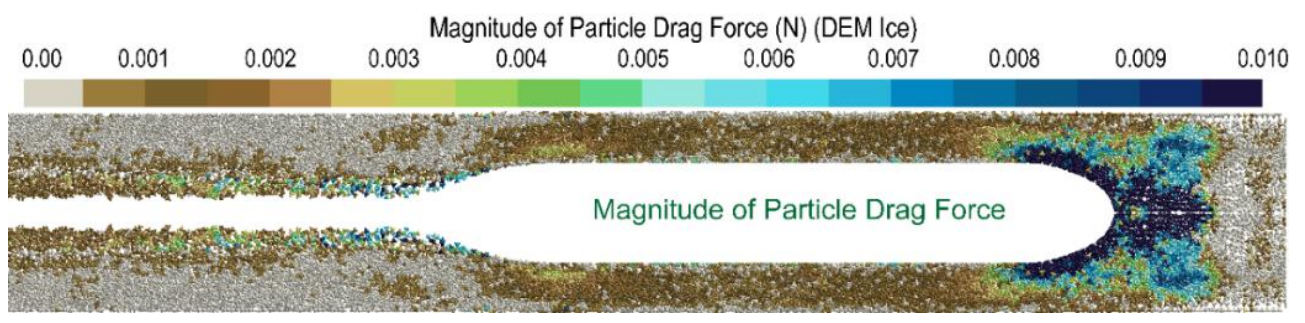


Fig.20 The distribution of drag force between brash ice particles and ship in brash ice channel

Fig. 21a, b, c show the distribution of axial, spanwise and vertical drag force between brash ice particles and ship in brash ice channel. The results presented in Fig. 21a show that the axial drag behavior of ice particles occurs in a wide range of areas, including the bow area, the wake area of ice particles and the ship side area. The spanwise drag force of ice particles is mainly distributed in the bow and wake regions of ice particles. Vertical drag force of brash ice particles is mainly distributed in the bow. The axial, spanwise and vertical drag characteristics of brash ice particles reflect the interaction between the ship and particles. The distribution of axial, spanwise and vertical drag in the bow region of the ship confirms that the brash ice particles move in many directions. Axial and spanwise distributions at the stern of the brash ice particles also confirm the axial and spanwise movement of the brash ice particles in the wake region.

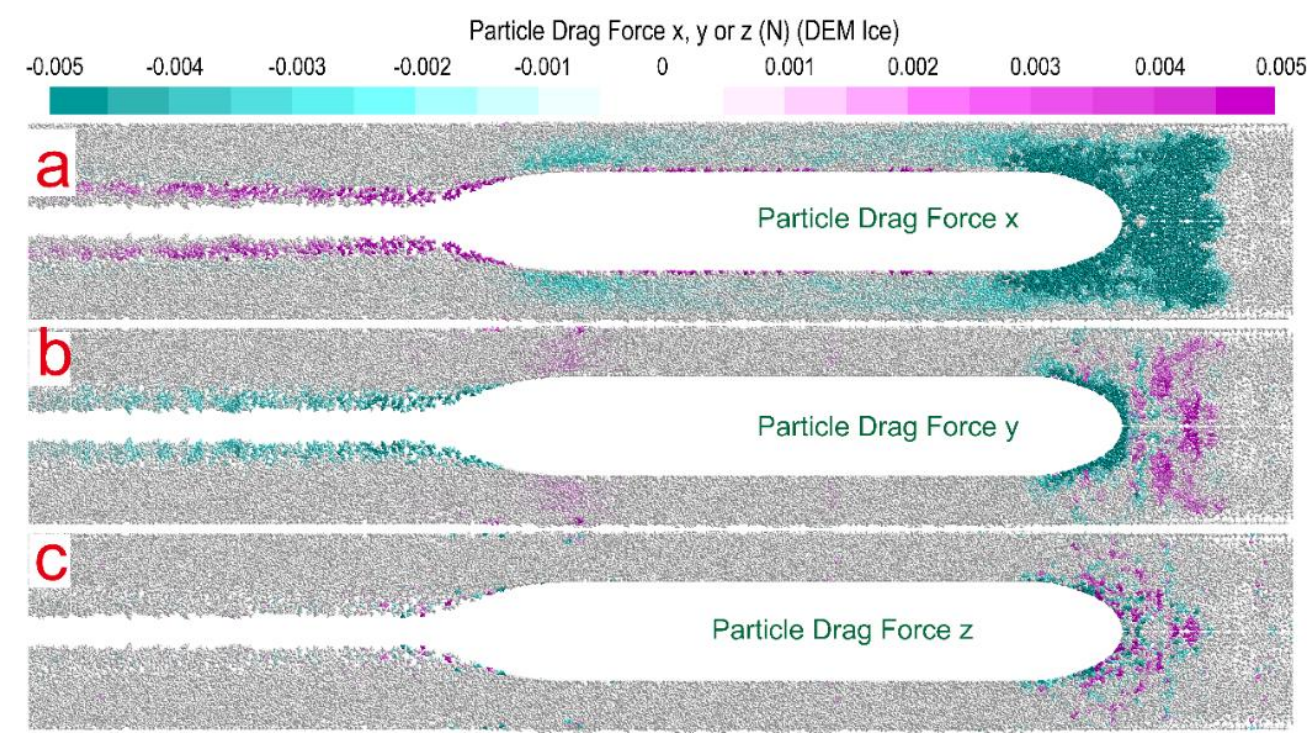

Fig. 21 Particle drag force $\mathrm{x}, \mathrm{y}$ and $\mathrm{z}$ of brash ice. a. the distribution of axial drag force; $\mathrm{b}$. the distribution of spanwise drag force; $c$. the distribution of vertical drag force).

\section{Conclusion}

An ice-strengthened bulk carrier navigates through brash ice channel was numerical studied base on CFD-DEM, and the resistance performance and the mechanism of ship-ice-water interaction in brash ice channel are analyzed. The results are summarized as follows:

a. The numerical simulation method of ship navigates in the brash ice channel using CFD-DEM is established based on the guide of HSVA experiment and the numerical results are consistent with the experimental data. The numerical ice particle model is built based on DEM method, the shapes of brash ice particles in the numerical simulation are represented by two geometric shapes, namely tetrahedral particles of isotropic and irregular polyhedral particles, according to the picture of brash ice in the HSVA ice towing tank, the contact and collision between particles and particles, particles and wall (ship hull and level ice) are solved using the Hertz-Mindlin 
model.

b. The influence study of ice particle shape on ship-ice interaction shows that the numerical method performs a better recurrence of the experimental phenomena in both ice shape, the sharp profile of ICE-1 is closer to that of model test ice particles and the similarity of experimental phenomena is much closer to ICE-1. And the maximum error, the minimum error and the average error of resistance prediction is better than ICE-2. In consideration of tetrahedral particles of isotropic has a better prediction effect based on numerical phenomena and resistance prediction accuracy, the tetrahedral particles of isotropic shape is more recommended in this study.

c. The influence study of coupling schemes on the ship-ice interaction process shows that the two-way coupling simulation can give a better and actual result for the structure-ice-water interaction with serious influence of the flow field on brash-ice behaviour. The average error of total resistance is $5.03 \%$ and $5.23 \%$ for the case of one-way coupling and two-way coupling, respectively. In actual condition, the interaction between ship-ice-water is two-way coupling, but the two-way coupling computing in CFD-DEM will occupy more computing resources than one-way coupling. For a low-speed simulation condition, the disturbance of the flow field and the two-way coupling effect between fluid and brash particles is not very significant, the one-way coupling is recommended for the less influential CFD-DEM case, resulting in the same calculation effect as two-way coupling at lower calculation cost.

d. In the process of ship-ice interaction, the overturning phenomenon exists due to collision between brash ice and ship. As the ship continues to sail, some brash ice accumulates at the bow and some brash ice slides toward the stern along both sides. The angular velocity distribution of brash ice in the brash ice channel which further confirms the description of the interaction phenomena of brash ice particles.

e. The studies of mechanical behavior of ship and particle interaction in the brash ice channel shows that the distribution area of contact force and drag force between brash ice particles and ship is mainly concentrated in the bow, around the hull and the wake area, this is because the above region has a large velocity gradient and particle action degree. The contact force and total resistance of ship-ice interaction displays an increasing trend in the early stage before the whole ship hull enters the brash ice channel. These two parameters stablizes when the whole ship hull enters the brash ice channel.

\section{Limitations of the study and future research}

Despite the advantages of CFD-DEM coupling in the simulation such as improving calculation accuracy, this methodology has some limitations. Some assumptions were made during the calculation. The shape of ice is irregular and random, and thus assumptions were made during the calculation process. Ice may break in the sailing process, and we assume that the brash ice will not be a secondary broken. Therefore, further studies are required to 
explore different parameters which are nearer to the practical situation. The breakup of ice should also be taken into consideration in future studies.

\section{Acknowledgements}

This work was financially supported by the National Natural Science Foundation of China (Grant No. 51679053); the Foundation of Pre-research on Military Equipment of the Chinese People's Liberation Army (Grant No. 6140241010116CB01005; JZX7Y20190252032901); the Aeronautical Science Foundation of China (No.201723P6001).The CFD-DEM numerical study of ship-water-ice interaction in this paper has been guided by Dr. Timothy Yen of CD-adapco (USA) and Dr. Xu Yongze of Siemens PLM Software, and we are deeply grateful for this.

\section{References}

Alberto, D. R., Francesco P. D. M., 2004. Comparison of contact-force models for the simulation of collisions in DEM-based granular flow codes. Chemical Engineering Science, Volume 59, Issue 3, 525-541.

Bateman, S. P., Orzech, M. D., Calantoni, J., 2019. Simulating the mechanics of sea ice using the discrete element method. Mechanics Research Communications, 99: 73-78.

Cundall, P., Strack, O., 1978. The Distinct Element Methods as a Tool for Research in Granular Media, Part I, Report to NSF.

Choi, J., Yoon, S. B., 2009. Numerical simulations using momentum source wave-maker applied to RANS equation model. Coastal Engineering, 56(10): 1043-1060.

Guidelines for the Verifications of a Ship's Performance for Ice Classes through Model Tests,2005. Guidelines for the Application of the Finnish-Swedish Ice Class Rules (edition of Dec. 2005).

Gong, H., Polojärvi, A., Tuhkuri, J., 2019. Discrete element simulation of the resistance of a ship in unconsolidated ridges. Cold Regions Science and Technology, 167: 102855.

Guo, C. Y., Wu, T.C., Zhang, Q., Gong, J., 2016. Numerical simulation and experimental research on wake field of ships under off-design conditions. CHINA OCEAN ENGINEERING, 30(5):821-834.

Guo, C. Y., Wu, T. C., Luo, W .Z. et al, 2018. Experimental study on the wake fields of a Panamax Bulker based on stereo particle image velocimetry. Ocean Engineering, 165: 91-106.

Hirt, C. W. and Nichols, B. D., 1981. Volume of fluid (VOF) method for the dynamics of free boundary. Compute Phys, 39:201-225

Haider, A. and Levenspiel, O. 1989. Drag coefficient andterminal velocity of spherical and nonspherical particles. Powder Technology, Vol. 58, 63-70.

Hansen, E. H., LØSET, S., 1999. Modelling floating offshore units moored in broken ice: model description. Cold 
Regions Science \& Technology, 29(2):97-106.

HSVA Report, 2012. Brash Ice Tests for a Panmax Bulker with Ice Class 1B.

Ji, S., Sun, S., Yan, Y., 2015. Discrete element modeling of rock materials with dilated polyhedral elements. Procedia engineering, 102: 1793-1802.

Johnson, K.L. 1987. Contact Mechanics, Cambridge University Press, Cambridge.

Kim, W.J., Van, D.H. and Kim, D.H., 2001. Measurement of flows around modern commercial ship models, Exp. in Fluids, Vol. 31, pp 567-578

Kim, M. C., Lee, S. K., Lee, W. J. et al, 2013. Numerical and experimental investigation of the resistance performance of an icebreaking cargo vessel in pack ice conditions. International Journal of Naval Architecture and Ocean Engineering, 5(1): 116-131.

Kim, J. H., Kim, Y., Kim, H. S. et al, 2019. Numerical simulation of ice impacts on ship hulls in broken ice fields. Ocean Engineering, 180: 162-174.

Lau, M., Lawrence, K. P., Rothenburg, L., 2011. Discrete element analysis of ice loads on ships and structures. Ships and Offshore Structures, 6: 211-221

Luo, W. Z., Guo, C. Y., Wu, T. C., Dai, S. S., Su, Y. M., 2016. Numerical Simulation of Viscous Flow Field around Ships in Ballast," Journal of Coastal Research 32(4), 911-922.

Morgan, D., Sarracino, R., Mckenna, R. et al, 2015. SIMULATIONS OF ICE RUBBLING AGAINST CONICAL STRUCTURES USING 3D DEM. International Conference on Port and Ocean Engineering under Arctic Conditions.

Morgan, D., 2016, An Improved Three- Dimensional Discrete Element Model for Ice-Structure Interaction, Proceedings of the 23rd IAHR International Symposium on Ice.

Menter, F. R., 1994. Two-equation eddy-viscosity turbulence models for engineering applications. AIAA journal, 32(8): 1598-1605

National Maritime Reasearch Inistitute (NMRI), 2015. A Workshop on CFD in Ship Hydrodynamics, Tokyo. http://www.t2015.nmri.go.jp/.

Norouzi, H., Zarghami, R., Sotudeh-Gharebagh, R. et al, 2016. Coupled CFD-DEM modeling formulation, implementation and application to multiphase flows. John Wiley \& Sons.

Raymond, A. Serway, 2018. Physics for Scientists and Engineers, Publisher: Cengage Learning, P.116.

Ranta, J., Polojärvi, A., 2019. Limit mechanisms for ice loads on inclined structures: Local crushing. Marine Structures, 67: 102633.

Seo, D. C. , Pallard, R. , 2016. A numerical study of interaction between ice particles and complex ship structures. 
Offshore technology conference arctic technology conference - st. johnl"s, Newfoundland and labrador, Canada.

Siemens PLM Software,2019. Simcenter STAR-CCM+® Documentation Version 2019.1. P-7482, 7486.

Sorsimo, A. , Heinonen, J., 2019. Modelling of ice rubble in the punch shear tests with cohesive $3 \mathrm{~d}$ discrete element method. Engineering Computations (1). https://doi.org/10.1108/ EC-11-2017-0436.

Su, B., Riska, K., Moan, T., 2010. A numerical method for the prediction of ship performance in level ice. Cold Regions Science \& Technology, 60(3):177-188.

Su, B., Riska, K., Moan, T., 2011a. Numerical study of ice-induced loads on ship hulls. Marine Structures, 24(2):132-152.

Su, B., Riska, K., Moan, T., 2011b. Numerical simulation of local ice loads in uniform and randomly varying ice conditions. Cold Regions Science \& Technology, 65(2):145-159.

Su, B., Skjetn,e R., Berg, T. E., 2014. Numerical assessment of a double-acting offshore vessel's performance in level ice with experimental comparison. Cold Regions Science \& Technology, 106-107:96-109.

Stephen, B. Pope, 2010. Turbulent Flows. United Kingdom: CAMBRIDGE UNIVERSITY PRESS.

Timco, G.W. and Weeks, W.F., 2010. A review of the engineering properties of sea ice - Cold Regions Science and Technology, 60, Elsevier Science Publishers B.V., Amsterdam, Netherlands, pp. 107-129,

Timco, G. W.,1984. Ice forces on structures: physical modelling techniques. In Second IAHR State-of-the-art report on ice forces on structures, special volume of proceedings IAHR symp on Ice, page 34.

Tuhkuri, J., Polojärvi, A., 2018. A review of discrete element simulation of ice-structure interaction. Philosophical Transactions of the Royal Society A: Mathematical, Physical and Engineering Sciences, 376(2129): 20170335.

VALANTO, P., 2007. Spatial distribution of numerically predicted ice loads on ship hulls in level ice. Report for Deliverable D6-3 of SAFEICE Project.

Vroegrijk, E., 2015. Validation of CFD+DEM Against Measured Data// ASME 2015, International Conference on Ocean, Offshore and Arctic Engineering: V008T07A021.

Wu, T. C., Zhang Q, Luo, W. Z. et al, 2017a. NUMERICAL SIMULATION AND EXPERIMENTAL STUDIES ON AFT HULL LOCAL PARAMETERIZED NON-GEOSIM DEFORMATION FOR CORRECTING SCALE EFFECTS OF NOMINAL WAKE FIELD[J]. Brodogradnja, 68(1):77-96.

Wu, T.C., Guo, C.Y., Luo, W.Z. et al, 2017b. CFD Predictions of Resistance and Viscous Flow Field around Ships for the JAPAN Bulk Carrier (JBC) without an Energy Saving Device[C]. 10th International Workshop on Ship and Marine Hydrodynamics. Keelung, China Taiwan, NO.350

Wu, T.C., Guo, C.Y., Luo, W.Z. et al, 2017c. Experimental and Numerical Study on the Wake Field of a 76000 
DWT Panamax Bulker, in: Proc. Int. Conf. Comput. Methods, 8th ICCM, Scientech Publisher, Guilin, pp. $813-820$.

Yulmetov, R., Bailey, E. and Ralph, F., 2017, “A Discrete Element Model of Ice Ridge Interaction with a Conical Structure", Proceedings of the 24th International Conference on Port and Ocean Engineering under Arctic Conditions (POAC'17).

Zhan, D., Agar, D., He, M. et al, 2010. Numerical simulation of ship maneuvering in pack ice, ASME 2010 29th International Conference on Ocean, Offshore and Arctic Engineering. American Society of Mechanical Engineers:855-862.

Zhou, L., Riska, K., Moan, T. et al, 2013. Numerical modeling of ice loads on an icebreaking tanker: Comparing simulations with model tests. Cold Regions Science \& Technology, 87(3):33-46.

Zhou, L., Riska, K., Ji, C., 2017. Simulating transverse icebreaking process considering both crushing and bending failures. Marine Structures, 54:167-187.

Zhou, L., Gao, J., Xu, S, et al, 2018. A numerical method to simulate ice drift reversal for moored ships in level ice. Cold Regions Science \& Technology, 152.

Zhang, N., Zheng, X., Ma, Q. et al, 2019. A numerical study on ice failure process and ice-ship interactions by Smoothed Particle Hydrodynamics. International Journal of Naval Architecture and Ocean Engineering. 